\title{
Acotaciones sobre la base conceptual de los principios generales del Derecho ${ }^{1}$
}

\author{
Alejandro González Monzón ${ }^{2}$ | Universidad de La Habana
}

Revista Derechos en Acción ISSN 2525-1678/ e-ISSN 2525-1686

Año 4/No 12 Invierno 2019 (21 junio a 20 septiembre), 759-829

DOl: https://doi.org/10.24215/25251678e325

\section{Precisiones preliminares sobre la cuestión terminológica}

La cuestión terminológica se presenta como una de las grandes disputas a tener en cuenta para el estudio de la categoría jurídica que interesa a los fines de estas páginas, llegando a acuñarse por parte de autores como Atienza y Ruiz Manero la factibilidad de referir diversos sentidos de la nomenclatura principio jurídico. ${ }^{3}$ La sustancia filosófica y la perspectiva de

1 Un estudio más extenso, profundo y detallado del autor sobre esta temática en GonzáleZ Monzón, A, Los principios generales del Derecho. Una manifestación de la complejidad del fenómeno jurídico, Bogotá, Leyer-UniAcademia, 2018, pp. 195-406.

2 Profesor de Filosofía del Derecho y Derecho Romano de la Facultad de Derecho de la Universidad de La Habana. Juez de la Sala Segunda de lo Civil y de lo Administrativo del Tribunal Provincial Popular de la Habana. alejandro.gonzalez@lex.uh.cu.

3 Siguiendo las consideraciones de CarRió ("Principios jurídicos y positivismo jurídico, "Notas sobre Derecho y lenguaje, Buenos Aires, Editorial Abeledo-Perrot, 1986) y GuAStinI ("Principi di diritto," Dalle fonti alle norme, Turín, Giappichelli, 1990), estos autores presentan las siguientes acepciones: "(...) Principio en el sentido de norma muy general, entendiendo por tal las que regulan un caso cuyas propiedades relevantes son muy generales; Principio en el sentido de norma redactada en términos particularmente vagos; Principio en el sentido de norma pragmática o directriz, esto es, de norma que estipula la obligación de perseguir determinados fines; Principio en el sentido de norma que expresa los valore superiores de un ordenamiento jurídico (y que son el reflejo de una determinada forma de vida), de un sector del mismo, de una institución; Principio en el sentido de norma especialmente importante, aunque se grado de generalidad pueda ser relativamente bajo; Principio en el sentido de norma de elevada jerarquía. Según este significado, todas las normas constitucionales 
intencionalidad política han dado al traste con una variedad de denominaciones trascendentes al espacio positivo, configurándose puntos de vista que, lejos de suponer una simple disputa lingüística, devienen en posicionamientos fundados sobre las funciones y la naturaleza jurídica de estos. Se agrega con esto un plus de oscuridad al tópico a tratar.

Si se parte de la raíz latina principium ${ }^{4}$ se puede caer en el facilismo de entender a los principios generales en el sentido exclusivo de origen o prima causa (en sentido cartesiano) de lo jurídico, magma de la que se desprenden las reglas y demás pautas organizacionales de la sociedad. ${ }^{5}$ Esto es cierto, pero no suficiente. Los prima principia de consistencia axiológica ${ }^{6}$ de los que habla Pérez LuÑo ${ }^{7}$ encajan en este razonamiento en virtud de ser también el Derecho una expresión de la moral media social. No obstante, ¿son los principios generales construcciones a priori en exclusiva? Lógicamente no lo son, pues

serían principios, incluyendo las que o parecen ser ni muy generales ni muy importantes; Principio en el sentido de norma dirigida a los órganos de aplicación jurídicos y que señala, con carácter general, cómo se debe seleccionar la norma aplicable, interpretarla, etc.; Principio en el sentido de regula iuris, esto es, de enunciado o máxima de la ciencia jurídica de un considerable grado de generalidad y que permite la sistematización del ordenamiento jurídico o de un sector del mismo. Tales principios pueden o no estar incorporados al Derecho positivo (...)". Atienza, M. y J. Ruiz Manero, "Sobre principios y reglas," Revista Doxa, No. 10, Alicante, 1991, pp. 104-105. Disponible en www.cervantesvirtual.com.

4 Algunas definiciones son las siguientes: “( ...) Primer instante del ser, de la existencia, de la vida // Razón, fundamento, origen// Causa primera// Fundamentos o rudimentos de una ciencia o arte// Máxima, norma, guía// (...)". Cabanellas de Torres, G, Diccionario Jurídico Elemental, Edición Electrónica a cargo de la Editorial Heliasta S.R.L, s/a, pp. 319-320; y “(...) Principio o comienzo. Dábase tal nombre a la primera de las tribus que votaba en los comicios y que por ello figuraba en la ley respectiva (...)". Ossonio, M, Diccionario de Ciencias Jurídicas, Políticas y Sociales, Ciudad de Guatemala, Editorial Datascan, S.A, Primera Edición Electrónica, s/a, p. 771.

5 Cfr. Guasp, J, Derecho, Madrid, Gráficas, S.L, 1971, pp. 291 y ss.

6 Al respecto vid las observaciones de Cossio sobre la dualidad que encierra la expresión principios generales del Derecho en cuanto su posibilidad de concreción como juicios estimativos supremos o como principios lógicos que estructuran el comportamiento jurídico. Cfr. Cossio, C, La plenitud del ordenamiento jurídico, Buenos Aires, Editorial Losada, 1947, pp. 151 y ss.

7 Pérez Luño, A. E, La seguridad jurídica, Barcelona, Editorial Ariel, 1994, pp. 30 y ss. 
de la elemental dialéctica entre lo genérico y lo particular se deduce que estos son también potenciales síntesis a posteriori, esto es, consecuencias de la ordenación positivada, ${ }^{8}$ e incluso, de la interacción de esta con otros elementos como los valores, las costumbres imperantes en un momento histórico dado, la jurisprudencia, o a través de un esfuerzo de creación doctrinal, tal y como ocurrió en el Derecho romano.?

La construcción léxica generales es igualmente polémica (potendo la stessa norma essere considerata principio generale rispetto a norme più specifiche, e norma specifica rispetto a una norma più generale). ${ }^{10}$ ¿Es sinónimo de universales? ¿Hace referencia a la generalidad ab intra de una institución, de una rama, de una materia o de todo el orden jurídico? Cualquier respuesta unilateral puede pecar de dogmática, lo que presenta cualquier variable como posible, ajustándose consecuentemente el campo aplicativo de los principios. La dificultad de realizar una medición adecuada del término en cuestión ha motivado en algunos autores, entre ellos RAz, su supresión de la estructura lingüística que se analiza. ${ }^{11}$

8 Para Moderne esta es la acepción más acertada, dado que “(...) ella permite insertar los principios en el cuerpo mismo del derecho y evitar así situarlos al exterior del derecho, como principios metajurídicos o ajurídicos (morales, políticos, sociológicos, etc.) (...)". Moderne, F, Principios generales del Derecho Público, Traducción de Alejandro Vergara Blanco, Santiago de Chile, Editorial Jurídica de Chile, 2005, p. 25. También de la explicación de Ascou se interpreta el abrazo de esta postura: "( ...) Mas los principios generales, siendo principios de derecho, presuponen un conocimiento de lo que sea el derecho en su carácter lógico y en su formación positiva, obtenido a través y más allá de sus normas; y si se encuentra la fuente de los principios generales, esta fuente debe aún explicar qué es, cómo nace, cómo se desarrolla el derecho; no sólo ayudar a encontrar las reglas para los casos no previstos por las normas positivas: allí debe residir, implícita o explícita, una teoría, una idea del derecho, de nuestro derecho positivo, y a través de ello, del derecho en general (...)". Ascolı, M, La interpretación de las leyes. Ensayo de Filosofía del Derecho, Buenos Aires, Editorial Losada S.A, 1947, p. 29.

9 Sobre la construcción de los principios en el Derecho romano vid, Mans Puigarnau, Los principios generales del Derecho. Repertorio de reglas, máximas y aforismos jurídicos con la jurisprudencia del Tribunal Supremo de Justicia, Barcelona, Bosch, Casa Editorial, 1947, p. XXXIII.

10 BoвBı, N, Contributi ad un dizionario giuridico, Torino, Giappichelli, 1994, p. 273.

11 Cfr. Raz, J, "Principles and the Limits of Law," The Yale Journal, No. 81. New Haven, 1972, p. 12 y ss. 
Por último, el hecho de circunscribir dichos principios generales al campo del Derecho puede tener connotaciones interesantes. ¿No pueden existir principios generales cuya matriz sea extrajurídica? De lo expuesto supra se infiere que esta contingencia es constatable. Principios como la bona fides, el alterum non laedare o el non bis in idem, son francos correlatos de la moral (los dos primeros) y de la lógica (el último), esferas que si bien son consustanciales a la ciencia del Derecho, también poseen independencia cognitiva. ${ }^{12}$

\section{Nociones sobre la inexistencia o existencia de los principios generales del Derecho. Relación de la complejidad de estos con la complejidad del fenómeno jurídico. Su carácter dinámico}

A la pretensión de conceptualizar a los principios generales del Derecho precede un escollo de naturaleza óntica que es necesario referir; éste se puede sintetizar en una interrogante: ¿existen los principios generales del Derecho o estos son pura entelequia? ${ }^{13}$ Es preciso dejar sentado ab initio que las teorías de negación no son mayoritarias en la doctrina, y que no todas tienen al positivismo clásico como intríngulis.

La raíz histórica de los posicionamientos negativos pude ser localizada en los debates franceses con respecto a la posibilidad de aplicar principios generales del Derecho bajo la sombra del Code.

La exégesis triunfante consideró que todas las construcciones teóricas tenían como génesis al derecho positivo. El culto

\footnotetext{
12 En opinión de Moderne: “(...) los principios extrajurídicos pueden influir respecto de un sistema de derecho, e integrarse en tanto que principios generales del derecho, no se debe olvidar que su origen debe ser buscado fuera del derecho mismo, y que ellos se prestan por este hecho a polémica en cuanto a la necesidad o a la efectividad de su juridicización, es decir, de su inserción en el derecho positivo (...)". Modernne, F, op. cit, p. 26.

13 Al respecto vid la sistematización realizada por DE CASTRO y BRAvo sobre las teorías negativas y positivas respecto a la existencia de los principios generales. Cfr. De Castro y Bravo, F, Derecho Civil de España, tomo I, Madrid, Editorial Civitas, S. A, 1984, pp. 408-410.
} 
extremo a la ley, la ignorancia de sus disímiles condicionantes y la repetición a ultranza de la misma como único modo de enfrentar los problemas prácticos, son los derroteros a seguir por los juristas. Al decir de Bugnet: “(...) yo no conozco el Derecho civil; y no enseño más que el Código de Napoleón (...)”. Por su parte Demolombe dejó claro que: "(...) mi divisa, mi profesión de fe, es ésta: los textos sobre todo (...)". ${ }^{14}$ De forma más categórica, pero en la misma línea expositiva, se localizan los argumentos de Valette: "(...) Se ha legislado tanto, sobre todo en los últimos 70 años, que sería muy extraño el que quedase un caso al cual no le fueran aplicables en algo las disposiciones legales (...)".15

Así, toda la labor interpretativa se inclinaba hacia la búsqueda de la ratio legislatoris, lo que mató irremediablemente las perspectivas históricas y sociológicas (luego defendidas por SAVIGNY) ${ }^{16}$ que debían servir de fundamentos al proceso de aplicación coherente del derecho en pos de su realización social plena. Según Laurent: "(...) los Códigos no dejan nada al arbitrio del intérprete; éste no tiene por misión hacer el Derecho; el Derecho está hecho (...)" ${ }^{17}$ Entender a la interpretación como una modalidad creativa está fuera de toda posibilidad.

Este movimiento supuso la ponderación de la deducción silogística en la aplicación del derecho. En reminiscencia matemática, habían de sumergirse en los contornos de la ley las peculiaridades del asunto, brindando la primera la extensión correspondiente en observancia de las consecuencias que de ella se derivan. En frase de Liard: “(...) los artículos del Código son teoremas cuyo alcance entre si hay que demostrar (...) el

14 Cit. pos, Gény, F, Método de interpretación y fuentes en Derecho Privado positivo, Madrid, Editorial Reus, S.A, 1925, p. 27.

15 Cit. pos, ReCAséns Siches, L, Nueva filosofía de la interpretación, México DF, Editorial Porrúa, 1956, p. 192.

16 Cfr. Savigny, F, De la vocación de nuestro siglo para la legislación y para la ciencia del Derecho, Prólogo de A. Posada, Madrid, La España Moderna, s/a, pp. 23 y ss.

17 Cit. pos, Gény, F, Método..., op. cit, p. 27. 
verdadero jurista es un geómetra y la educación puramente jurídica es puramente geométrica (...)".18

La sistematización de estos postulados por el positivismo jurídico, donde tuvo un espacio importante la esquematización metodológica de Kelsen, ha sido una plataforma coherente desde donde construir todo tipo de argumentos con respecto a la inexistencia de los principios generales del Derecho. No obstante, desde ángulos analíticos igualmente positivistas, se ha reparado, a modo de matización, sobre la existencia de construcciones que, atendiendo a determinados condicionamientos, trascienden a las reglas positivadas. Cuestión que complejiza notablemente el asunto y que niega el simplismo tendente a establecer una igualdad entre iuspositivismo y antiprincipalismo.

\section{II.1. La teoría pura de Hans Kelsen y su implicación negativa en torno al principalismo. La reacción de Josef Esser}

El contrapunteo de ideas kelsenianas y esserianas es fundamental para comprender los caminos seguidos en el mundo anglosajón al tenor de las obras de HART y DwOrKIn, no olvidando las precisiones posteriores de Alexy, todo lo cual constituye un corpus teórico con sólida virtualidad en el presente.

La lógica metodológica de la teoría pura ${ }^{19}$ y las implicaciones que le suceden, son cuestionadas desde estribos de naturaleza sociológica, lo que tuvo como resultado el esbozo de disímiles situaciones prácticas donde la idea del imperio absoluto de la norma no aportaba respuestas cabales. Si bien la esencia de la polémica no descansa cardinalmente en lo concerniente a los principios, estos si constituyen en su desarrollo un instrumento indispensable a través del cual figurar una ontología del Derecho coherente. Así, la importancia de analizar los aspectos

\footnotetext{
18 Cit. pos, Gény, F, Método..., op. cit, p. 58.

19 Apud Kelsen, H, Teoría general del Derecho y del Estado, Traducción de Eduardo García Márnez, México, Imprenta Universitaria, 1949, pp. 4-6.
} 
fundamentales de esta pugna, radica en que a través de ella los principios generales del Derecho pueden ser apreciados como piezas integrantes del fenómeno jurídico, entendido este en su más estrecha unidad, lo que constituye un presupuesto esencial para, con posterioridad, detenerse en su configuración iusfilosófica, en el lugar que ocupan en el ordenamiento jurídico y en las funciones que realizan.

El enfrentamiento de estas dos miradas globales sobre el saber jurídico y su consecuente expansión, permite también llegar a conclusiones que explican, desde posicionamientos diferentes, la trascendencia de aceptar a los principios generales dentro del esquema científico del Derecho. A través de ella se puede sopesar la posibilidad metodológica de estudiar al fenómeno jurídico dentro de parámetros epistemológicos más o menos flexibles, a la vez que presenta lo referido al condicionamiento ético como pendiente a tener en cuenta en todos los ejercicios de conceptualización que tengan por objeto a un segmento de la realidad jurídica.

\section{II.1.1. Kelsen y el principalismo}

La pureza metodológica de Kelsen, que para Aftalion constituyó un giro copernicano en los estudios jurídicos, ${ }^{20}$ resume, en alguna medida, las aspiraciones despertadas por el ímpetu codificador del siglo XIX, que tuvo en Francia una connotación importante en el campo de la iusfilosofía al calor de la exégesis. ${ }^{21}$ La aspiración kelseniana, expuesta con precisión en el prólogo a la primera edición de su Teoría pura, consistió en depurar al saber jurídico de todo vestigio histórico, ideológico,

\footnotetext{
20 Apud Aftalion, E. R, Critica del saber de los juristas, La Plata: s/e, 1951, pp. 22 y ss.

21 Cfr. Cappeluini, P, “Códigos," Fioravanti, M, El Estado Moderno en Europa. Instituciones y derecho, Madrid, Editorial Trotta, 2004, pp. 117-118. Sobre las fases de esta Escuela (fundación, 1804-1830; apogeo, 1830-1880; y decadencia, 1880-1900) y sus representantes más cabales (Delvincourt, Toullier, Melville, Duranton, Marcadé, Laurent, Baudry-Lacantinerie, entre otros) vid, Hernández-Gil, A, Metodología del Derecho. Ordenación crítica de las principales direcciones metodológicas, Madrid, Editorial Revista de Derecho Privado, 1945, pp. 56-57.
} 
político, sociológico y ético, ${ }^{22}$ encuadrando su pensamiento en los cánones de constatabilidad matematizada del positivismo continental de inicios del siglo XX. ${ }^{23}$

Así, la asunción del método normativo era la única alternativa viable para contener al Derecho en cánones de cientificidad, ${ }^{24}$ en virtud de ser su objeto de estudio localizado en el mundo del deber ser. Para cumplimentar estos objetivos asume las directrices kantianas sobre las ciencias normativas, ${ }^{25}$ arrojando su sistema, en este sentido, cuatro postulados de raigal trascendencia, a saber: la exclusividad de la ciencia jurídica, el monismo metodológico, la separación sein-sollen y la neutralidad. ${ }^{26}$

La reflexión en torno a los principios jurídicos pende de estos cuatro postulados. Ahora bien, negar categóricamente la existencia de principios en las construcciones de Kelsen puede conducir al equívoco de entender su teoría desde posicionamientos ontologistas. ${ }^{27} \mathrm{Al}$ contrario, hay en el vienés rastros de

22 En este espacio dejo sentadas sus aspiraciones, consistentes en la elaboración de: “( . ..) una teoría que estuviese depurada de toda ideología política y de todo elemento proveniente de las ciencias naturales, una teoría que fuera consciente de su carácter peculiar en razón de la legalidad propia de su objeto (...)". Un poco más adelante reiteraba que: "(...). Desde el comienzo mi meta fue elevar la jurisprudencia que, abierta o veladamente, se había convertido en reflexión político-jurídica al nivel que es consustancial a una verdadera ciencia, en concreto al nivel de una ciencia natural. La tarea consistía en profundizar en las tendencias del pensamiento jurídico que solo tenían como norte el conocimiento del derecho, y no de qué manera debía ser configurado materialmente; se trataba asimismo de aproximar lo más posible sus resultados al ideal que preside toda ciencia: la objetividad y la exactitud (...)". Kelsen, H, Teoría pura del derecho. Introducción a los problemas de la ciencia jurídica, Madrid, Editorial Trotta, 2011, p. 35.

23 Apud Treves, R, Il fondamento filosofico della dottrina pura del diritto di Hans Kelsen, Torino, Accademia delle Scienze, 1934, pp. 20 y ss. También vid, Calsamigla, A, En defensa de Kelsen, Barcelona, Working Paper No.129, 1997, in integrum.

24 Cfr. Sánchez de Bustamante y Montoro, A, Teoría general del Derecho, La Habana, Cultural, S.A, 1953, pp. 21-35.

25 Cfr. Vega, J, La idea de ciencia en el derecho, Oviedo, Editorial Pentalfa, 2000, pp. 107 y ss.

26 Una explicación suficiente en García López, D. J, Organicismo silente. Rastros de una metáfora en la ciencia jurídica, Granada, Editorial Comares, 2013, pp. 224 y ss.

27 A juicio de Comanduccl: "(...) el positivismo metodológico (...) sólo afirma la que puede llamarse como tesis de la no conexión identificativa necesaria entre Derecho y moral: en 
principalismo, sólo que condicionados al despliegue normativo, esto es, al ejercicio deductivo exclusivo de la dinámica positiva del Derecho. Desde esta óptica fue claro al expresar en su obra póstuma que: "(...) tales principios no tienen carácter de normas jurídicas. Si no se separa claramente el concepto de norma jurídica y el concepto de principio jurídico, entonces se borra el límite entre el derecho positivo, por un lado, y, por otro, la moral, la política y las costumbres, lo cual sólo puede ser deseable para tales representantes de la ciencia del derecho, que creen que su tarea consiste no tanto en conocer el derecho positivo y describirlo objetivamente, sino más bien en justificar o cuestionar su validez desde el punto de vista de la moral y la política (...)". ${ }^{28}$

No caben dudas que la reacción de Kelsen se sustenta en la negación de oxigenar el Derecho con elementos supra normativos, o lo que es lo mismo, en el impedimento de que la categoría principios quiebre la pureza jurídica y devenga en argumento positivo en cuanto a la concepción de canales comunicativos entre este saber y la ética, la política, la costumbre como correlato sociológico, entre otros espacios, siempre desde una perspectiva metodológica.

\section{II.1.2. La respuesta de Esser}

La estrechez de condicionamientos que propone Kelsen para con el Derecho, es la base de la crítica que desarrolla Esser en

otras palabras, la tesis según la cual no hace falta que el teórico, para identificar el Derecho, asuma un punto de vista moral. Para el positivismo metodológico, siguiendo a Kelsen, es la teoría la que debe ser pura, no el Derecho, que de hecho puede tener y tiene muchas conexiones con la moral. Por ejemplo, un positivista metodológico puede admitir sin dificultad que hoy, en la praxis de los tribunales, especialmente de los constitucionales, se recurre a principios morales. Esta praxis está estimulada por los partidarios de la tesis de la separación fuerte, la cual probablemente, más que como una teoría, es interpretable como una doctrina normativa que sugiere, entre otros, a los jueces (...) una lectura moral de la constitución (...)". Comanducci, P, Principios jurídicos e indeterminación del Derecho, Génova, Universita'degli studi di Genova, Dipartimento di Giurisprudenza, Edición digital, s/a, p. 9. También vid, Kelsen, H, "La doctrina del derecho natural y el positivismo jurídico," Academia. Revista sobre Enseñanza del Derecho, No. 12, Año 6, 2008, pp. 183-198.

28 Kelsen, H, Teoría general de las normas, México DF, Editorial Trillas, 1994, p. 125. 
su obra. ${ }^{29}$ Para este autor alemán los presupuestos éticos del Derecho adquieren una importancia vital a la hora de definir e identificar los límites conceptuales y la funcionalidad orgánica de los principios jurídicos, tanto en su rol creativo como en su instrumentalidad interpretativa.

En consecuencia, propone una clasificación entre los principios del Derecho en sentido estricto, que irradian tanto el ámbito material como el formal de este fenómeno, y los principios jurídicos a través de los cuales este se aplica. ${ }^{30}$ Así, dibuja una solución dual que supera la rigidez kelseniana, aunque en buena técnica contiene sus argumentos. ${ }^{31}$ Introduce igualmente en sus razonamientos variables sociológicas en virtud de dinamizar las estructuras de las fuentes del Derecho, partiendo de cuestionarse a partir de qué momento poseen los principios jurídicos el carácter de derecho positivo, a lo que responde que: "(...) desde y en la medida en que han sido encarnados en una institución, por un acto constitutivo del poder legislativo, de la jurisprudencia o de la vida jurídica (...) Dentro de este marco, todos los principios jurídicos son elementos del derecho positivo que gozan de protección procesal, tanto si aparecen como principios sistemáticos o constructivos del derecho material, o como máximas, premisas y reglas técnicas, como figuras fundamentales y comunes a todos los derechos civilizados o como simples reglas técnicas del pensamiento y de la labor jurídica (...)". ${ }^{32}$

29 Cfr. Essen, J, Principio y Norma en la elaboración jurisprudencial del Derecho Privado, Barcelona, Casa Editorial Bosch, 1961, pp. 52 y ss.

30 Cfr. Esser, J, op. cit, pp. 137 y ss.

31 Apreció este autor que: "(...) Esta distinción parece a primera vista objetiva y definitiva, si paramos mientes sobre todo en el carácter heurístico de los principios del descubrimiento del Derecho, en las reglas de la interpretación, de la distribución de la carga de la prueba, etc. (...); la consideración histórica ve en ellos la base para el nacimiento del derecho objetivo a partir de la experiencia judicial; una concepción ahistórica, pero sociológica, ve también en las reglas de una técnica procesal adecuada al fin de protección presupuesto, un factor de carácter constitutivo para la tarea de entresacar normas objetivas de entre las disposiciones positivas sujetas a tantas mutaciones (...)". EsSER, J, op. cit, p. 137.

32 EsSER, J, op. cit, p. 169-171. 
Como se puede apreciar, el concepto vida jurídica utilizado por EsSER sirve como válvula de escape ante toda minimización irracional de los principios, derrumbando las infranqueables barreras dibujadas por KELSEN en torno a lo que es derecho positivo y lo que no lo es. Consiguientemente, los principios jurídicos son derecho positivo y guías informadoras para los órganos formadores del derecho a la vez, ${ }^{33}$ salvando que los llamados pensamientos jurídicos generales, las rationes legis, los principios valorativos y constructivos de un sistema y los principios éticos y de justicia, si bien comparten este atributo siempre que hayan obtenido validez en formas concretas del ordenamiento, no son reglas precisas e independientes. ${ }^{34}$

\section{Sistematización y crítica de algunos criterios negativos con respecto a la existencia de los principios generales del Derecho}

Han sido variados los criterios presentados como baluartes de negatividad en lo que a principios generales del Derecho interesa. La abstracción, la imposibilidad de delimitación, la duda sobre su operatividad, la sinonimia con las reglas, ${ }^{35}$ entre otros, han devenido en argumentos de ataque que permiten, aparentemente, razonar en sede jurídica si atender a tan complicada categoría.

El caso de Alchourrón y Bulygin pende de las derivaciones de un realismo llevado hasta sus máximas consecuencias, lo que los conduce a entender, tomando como presupuestos al principio de economía de JHERING y a lo que dieron a llamar norma

\footnotetext{
33 Agrega que: "(...) También estas, usadas lege artis, pueden entrar bajo garantías de las reglas reconocidas para el descubrimiento del derecho y ser protegidas como partes positivas del derecho, independientemente de las figuras singulares a cuya creación han dado lugar (...)". ESSER, J, op. cit, p. 171.

34 Cfr. Esser, J, op. cit, p. 171.

35 Cfr. Bulloch, P. A y J. Raz, La decisión judicial. El debate Hart-Dworkin, Estudio preliminar de César Rodríguez, Bogotá, Facultad de Derecho de la Universidad de los Andes, 2005, pp. 48 y ss.
} 
compleja ${ }^{36}$ que la única posibilidad de existencia de los principios generales del Derecho está condicionada a un ejercicio inductivo que los extraiga del sistema normativo o de la jurisprudencia. Si bien no caben dudas de la efectividad de este proceso, lo negativo de su planteamiento es el ataque a la independencia principalista, esto es, la sujeción de la realidad de los principios a una realidad jurídica necesariamente anterior que les sirva de fuente. ${ }^{37}$

La respuesta de Pérez Luño, que sigue los derroteros de SAnti Romano en torno a la mitología jurídica, ${ }^{38}$ es categórica,

36 Alchourrón, C. E. y E. Bulygin, Introducción a la metodología de las ciencias jurídicas y sociales, Buenos Aires, Editorial Astrea, 1993, pp. 126 y ss.

37 Apuntan estos autores que: “( . . .) La reformulación de la base de un sistema jurídico se ha considerado tradicionalmente una de las tareas más importantes de la ciencia dogmática del derecho, puesto que tal reformulación va íntimamente ligada a la elaboración de las denominadas partes generales y de los principios generales del derecho (...). La finalidad principal de la reformulación radica, por consiguiente, en el hallazgo de normas generales, es decir en la sustitución de una pluralidad de normas por una norma más general (...); la reformulación del sistema consiste en la sustitución de la base del sistema por otra base nueva -más reducida y general-, pero normativamente equivalente a la base primitiva. Este último requisito es muy importante: sólo si la nueva base tiene las mismas consecuencias normativas que la base anterior puede hablarse de reformulación del mismo sistema; si la nueva base no recoge alguna de las consecuencias normativas de la base primitiva o tiene consecuencias que ella no tenía, no se tratará ya del mismo sistema, sino de dos sistemas diferentes (...). Lo que hemos dicho acerca de la reformulación se aplica por igual a la elaboración de las partes generales de las distintas materias y a la extracción de los llamados principios generales del derecho. Todo parece indicar que ambas actividades consisten, sustancialmente, en lo mismo: la formulación de normas cada vez más generales (... .)". AlchourRón, C. E. y E. Bulygin, op. cit, pp. 129-132.

38 En palabras de este autor italiano: “(...) Es superfluo destacar que el mito no es verdad o realidad, y hasta que es lo opuesto y, por consiguiente, la mitología jurídica debe contraponérsela a la realidad jurídica (...). De todos modos, en evitación de equívocos, convendrá recordar y precisar que la verdad o realidad jurídica es la que ha sido acogida o hasta incluso creada por un determinado derecho positivo, aunque sea diferente de la realidad que, en contraposición a la puramente jurídica, se dice efectiva, o de hecho, o material y, por consiguiente, aunque sólo existe en la conciencia de un ordenamiento jurídico, con tal de que él sea vigente y operante. (...)". Romano, S, Fragmentos de un Diccionario Jurídico, Buenos Aires, Ediciones Jurídicas Europa-América, E.J.E.A., S.A, 1964, p. 226. A simili, Grossı muestra interesantes conclusiones sobre esta cuestión: "(...) Para esto sirve el mito en su significado esencial de transposición de planos, de proceso que compele a una realidad a completar un 
dado que para este autor español: “(...) los principios generales del derecho son un mito jurídico, pero un mito que responde a una necesidad propia de los ordenamientos jurídicos de los Estados de derecho: reconocer el valor de la seguridad jurídica (...)". ${ }^{39}$ Se observa que si bien cataloga este tratadista a los principios como expresión de la mitología jurídica, ejercicio que no compartió en su tiempo el propio Romano, pues para él estos eran una materialización del ius involuntarium (en oposición al ius voluntarium asumido como derecho positivo emanado de la autoridad estatal), basándose en comprenderlos como meras abstracciones imaginarias que no se pueden entender, no cuestiona su instrumentalidad. ${ }^{40}$

Con estos razonamientos Pérez LuÑo pone sobre la mesa una interesante paradoja: ¿mitos instrumentales? ¿Imágenes inexistentes de profundo calado funcional? Se considera que el autor comentado redunda en un posicionamiento de inclinación positivista, puesto que si bien la abstracción, en potencia, caracteriza a los principios generales, esto no es motivo suficiente para

vistoso salto a otro plano transformándose en una metarrealidad; y si toda realidad está en la historia, de la historia nace y con la historia cambia, la metarrealidad constituida por el mito se convierte en una entidad metahistórica y, lo que es más importante, se absolutiza, se convierte en objeto de creencia más que de conocimiento. El resultado estratégicamente negativo derivado de la secularización sólo puede ser exorcizado con el bosquejo mitológico (...)". Grossı, P, Mitología jurídica de la Modernidad, Madrid, Editorial Trotta, 2003, p. 41. También vid, García Pelayo, M, "Mitos y símbolos políticos" y “Del mito y de la razón en la historia del pensamiento político," Obras Completas, Vol. I y II. Madrid, Centro de Estudios Constitucionales, 1991, pp. 907-1031 y 1033-1240, respectivamente.

39 Pérez Luño, A. E, "Los principios generales del Derecho: ¿un mito jurídico?" Revista de Estudios Políticos (Nueva Época), No. 98, Madrid, octubre-diciembre de 1997, p. 22.

40 Entiende Pérez LuÑo que: "(...) incumbe a los principios el ser una cláusula de cierre del sistema de fuentes del derecho. Gracias a esa pretendida fuente normativa los tribunales, aun en defecto de ley y costumbre, podrán recurrir a esos imaginarios principios generales del derecho susceptibles de dar respuesta jurídica a todos los conflictos que puedan surgir en el seno de los sistemas jurídicos. Al propio tiempo, y para tranquilidad de la seguridad jurídica, el recurso a los principios crea la ilusión de que así se evitan los riesgos e incertidumbres que comporta siempre el reconocimiento del arbitrio judicial, de la función normativa de la doctrina científica, o de la apelación a las distintas versiones del derecho natural (...)". Pérez LuÑo, A. E, Los principios..., op. cit, p. 22-23. 
tildarlos de entes que no existen..$^{41}$ Se desconocen así categorías filosóficas esenciales. Lo ideal o abstracto no es un concepto antagónico con respecto a lo real. Toda construcción abstracta es, en efecto, real, en tanto resultado de un proceso creativo que se objetiva en determinadas esferas sociales. En este caso en particular, los principios generales del Derecho son, aunque no en todos los casos, arquitecturas abstractas objetivadas históricamente en el espacio jurídico.

Otro autor que niega la existencia de los principios generales del Derecho, esta vez desde una perspectiva realmente empobrecida en comparación con la de Pérez Luño, es Rafael HERNÁNDEZ MARín. En su exposición sobre la concepción estándar y la concepción realista del Derecho, entiende que la primera es aquella que: "(...) se enseña a los alumnos de las facultades de Derecho, en las aulas y en los libros de texto, y que es compartida por la mayoría de los juristas (...)”. Configurándose como tesis central de esta concepción: “(...) la afirmación de que los componentes esenciales del Derecho son la ley (concebida idealmente), el Derecho consuetudinario y los principios generales del Derecho (...)". A contrario sensu, llama realista pura a la que sostiene: "(...) que del Derecho solamente forma parte la ley; y además que la ley es un hecho (...)”. Implicando esta concepción realista: “(..) 1) que no hay más Derecho que el Derecho positivo; 2) que no hay más Derecho positivo que la ley; 3) que no hay más ley que el texto de la ley; y 4) que ese texto legal es un hecho, un objeto físico (...)". ${ }^{42}$

No es necesario advertir que el abrazo de la directriz realista pura por parte de este autor inhabilita la posibilidad existencial de los principios generales, resultando curioso que, dado el desarrollo iusfilosófico operante en España al momento de realizarse dicho juicio, se enarbolen esquemas de razonamientos

\footnotetext{
41 Pérez luño, A. E, Los principios..., op. cit, p. 21.

42 Hernández Marín, R, "La concepción estándar y la concepción realista del Derecho," Anuario de Filosofía del Derecho, Nueva Época, Tomo XII, Madrid, Ministerio de Justicia e Interior, Secretaría General Técnica, 1995, pp. 347-348.
} 
de tan marcado normativismo. Con gracejo tilda el precitado autor de idealistas a aquellos que entiendan al Derecho más allá del derecho positivo, cuando, en buena técnica hegeliana, toda su teoría es idealista, pues estudia un fenómeno (el jurídico) en una de sus aristas y no en su totalidad, apartando, no metodológica sino ontológicamente, aspectos que ciertamente le conciernen.

Un poco más moderado, aunque igualmente tendente al positivismo, es el posicionamiento de PrIETO SANChís. ${ }^{43}$

La moderación de su criterio radica en dos cuestiones, a saber: la consideración de la costumbre, proscrita en la concepción realista pura, y la aceptación de la concurrencia de los principios generales en lo que a interpretación del Derecho interesa, incluso con el apelativo de creación del mismo. No obstante, su limitación a la actividad interpretativa y al desprendimiento normativo de los principios $^{44}$ hace que su

43 Según este autor: "( ...) los principios no existen como fuente anterior a la interpretación (...) aluden a una entidad fantástica (...)". Apostillando más adelante que: "(...) en realidad, bajo los Ilamados principios generales del Derecho no se esconde más que un Ilamamiento a la producción jurídica por vía de razonamiento o argumentación, suponiendo que se pueden obtener normas a partir de normas (...); los principios generales del Derecho, al igual que el muy cercano argumento analógico, constituyen, pues, un caso de creación de Derecho en sede interpretativa. Esto significa que las fuentes del Derecho no son en pie de igualdad la ley, la costumbre y los principios generales, sino más bien la ley, la costumbre y sus consecuencias interpretativas (...)". Prieto Sanchís, L, Ley, principios, derechos, Madrid, Editorial Dykinson, 1998, pp. 49-50.

44 Una visión diferente es la ofrecida por Hermann Heller en su Teoría del Estado: “(...) El precepto jurídico recibe toda su fuerza moral obligatoria exclusivamente del principio ético del derecho, supraordenado. Este principio del derecho, sin embargo, se distingue del precepto jurídico por su carencia de seguridad jurídica o certeza jurídica, que consiste, de una parte, en la certidumbre de su sentido, en la determinación del contenido de la norma, y, de otra parte, en la certeza de su ejecución (...). Los principios del derecho proporcionan sólo las directrices generales sobre cuya base debe establecerse el status jurídico entre los miembros de la comunidad jurídica; no suministran una decisión para el caso concreto. Fáltales para ello el carácter de determinación taxativa, o sea, que se precisa siempre de una decisión sobre lo que, en una situación de intereses determinada espacial, temporal y personalmente, debe ser derecho según aquellos principios. Sobre la base de idénticos principios jurídicos cabe que sean posibles (y a veces incluso tienen que serlo) decisiones jurídicas diversas, lo mismo ordenaciones jurídicas, constituciones que leyes, sentencias y 
análisis, si bien no erróneo, devenga insuficiente, lo que bajo ninguna circunstancia significa rechazar que en el proceso de concreción de los principios ${ }^{45}$ se tenga como presupuesto un ejercicio de interpretación. Sin embargo, se defiende al calor de esta exposición una variante que los entiende desde una óptica de funcionalidad superior en el ordenamiento jurídico.

Visto lo anterior, resulta atinado llegar a una conclusión intermedia que ha de guiar toda la exposición subsiguiente: la existencia plena de los principios generales del Derecho sólo puede ser defendida coherentemente desde una visión compleja y multidimensional del Derecho. Así, según la visión ontológica de la que participe el jurista, los principios serán concebidos como reservorio de los fundamentos, como la esencia, como la verdad misma del Derecho o, en sentido opuesto, como arquetipos del lenguaje o del metalenguaje jurídico utilizados como herramientas discursivas, siendo la misión del operario el manejo de significados disímiles en relación con la función que de estos se pretenda. Por esta razón, es indispensable dejar pautas de la concepción óntica de la que se trae causa.

\footnotetext{
actos administrativos. Pero tanto la certidumbre de sentido como la certidumbre de ejecución requieren la existencia de un poder autoritario que declare y ejecute lo que en cada situación concreta debe ser derecho (...)". Heller, H, Teoría del Estado, Versión española de Luis Toвío, México, Fondo de Cultura Económica, 1942, pp. 248-249.

45 Según GuAstinı, que como es conocido participa en lo que interesa al tema de un no cognitivismo ético que deriva en un relativismo ontológico que entiende a los principios generales como meras construcciones del lenguaje carentes de esencia: "(...) D'altro canto, le norme inespresse servono non solo per colmare lacune (vere o presunte), ma anche per concretizzare principi. I principi, essendo altamente indeterminati (fattispecie aperta, contenuto generico, derogabilità, etc.), non sono atti a fornire direttamente la soluzione di una controversia. Nel senso che non possono fungere da premesse in ragionamenti deduttivi - Gli assassini devono essere puniti. Tizio è in assassino. Quindi Tizio deve essere punito - la cui conclusione è un precetto individuale e concreto. Per contribuire alla soluzione di controversie, i principi devono essere concretizzati. Concretizzare un principio consiste nell'usarlo come premessa in un ragionamento normalmente non deduttivo - per costruire una regola inespressa, essa si idonea a risolvere la controversia (...)". GUASTINI, R, "Interpretare, costruire, argomentare," Osservatorio sulle fonti, 2915, p. 23. Disponible en www.osservatoriosullefonti.it.
} 


\section{Perspectivas doctrinales sobre la conceptualización y las diferentes formas de manifestación de los principios generales del Derecho}

Lo referido a los principios generales del Derecho es una cuestión que irradia en todos los espacios del saber jurídico, desde todos ellos se pueden arrojar conclusiones que enriquezcan lo concerniente a su concepto, naturaleza, funcionalidad, caracteres, entre otros pendientes. Esto se explica por la sencilla razón de ser diferenciado, en la mayoría de las ocasiones, el rol que estos desempeñan en cada uno de esos espacios, ya sea en su condición de fuente, de elemento orientador, de pauta argumentativa, o cualquier otra de sus funciones, situación que enmaraña, a la vez que enriquece todo acercamiento concienzudo al tema. No obstante, ha sido meridiana la opinión de De Diego, ${ }^{46}$ en tanto compete a la Teoría y a la Filosofía del Derecho arrojar los fundamentos ontológicos y epistemológicos que permitan dibujar un cuadro explicativo cabal de esta complejísima categoría jurídica.

Tras los intentos de conceptualización de los principios generales del Derecho, marcados muchas veces por la ambigüedad y el relativismo, tanto en su dimensión y significación externa (sentido del nomen), como en el contenido mismo que le es propio, se esconde una maleza iusfilosófica que ha fungido como plataforma condicionante. Es claro que un ejercicio de tanta relevancia ha de estar en íntima consonancia con la visión genérica que del fenómeno jurídico se tenga, pues los principios

\footnotetext{
46 El tema de la disertación -dice DE DIEGo- es harto sugestivo y sobre él: "( . . ) se han pronunciado en abundante literatura la Filosofía y la Dogmática jurídicas; como que representa uno de los más claros y fuerte vínculos de conexión y enlace entre una y otra disciplina. Considerados, en efecto, los principios generales del derecho en su más alto y comprensivo sentido son materia propia del filósofo del derecho; empero, hallándose ellos en la raíz misma de las instituciones jurídicas particulares no pueden ser extraños al jurista profesional y éste pertenecen desde luego y dentro de su competencia están, cuando descienden de aquellas alturas para encarnar en la vida prestando espíritu, color y base a los preceptos de una legislación positiva (...)". DE Diego, C, “Prólogo," Del Vecchio, G, Los principios generales del Derecho. Traducción y Apéndice de Juan Ossorio Morales, Barcelona, Editorial Bosch, 1993, p. VI.
} 
generales son un puntal cardinal en la construcción metodológica de la ciencia jurídica. ${ }^{47}$ Lo que le ha permitido asumir diferentes ropajes en el devenir de la historia del pensamiento.

Delinear los contornos del objeto que interesa a esta investigación, muchas veces representado no como un concepto unitario sino como una famiglia numerosa e piuttosto eterogenea di concetti, ${ }^{48}$ deviene en una actividad intelectual polémica, para nada agotada, permeada de contradicciones, de retrocesos y de posturas que si bien en algunos casos comparten visiones comunes, en otros son claramente antagónicas. ${ }^{49}$ Realizándose así la máxima de BoвBı que reza "(...) con questa espressione (la de principios generales del Derecho) si intendono spesso cose molto diverse, anche se non sempre ce ne rendiamo conto (...)".$^{50}$ Este dinamismo y esta confusión que sirven de aureola al análisis que se realiza es una muestra proporcional a la magnitud de su importancia.

47 Al decir de Manuel Aragón: "(...) Al margen de las diferencias de razonamiento, la admisión de los principios jurídicos será, pues, un lugar común en la Ciencia del Derecho, incluidos los diversos sectores del positivismo jurídico con la sola excepción del normativismo kelseniano. La jurisprudencia de conceptos, la jurisprudencia de intereses, la jurisprudencia sociológica, la jurisprudencia valorativa, a lo largo del siglo XIX y el primer tercio del XX, y por vías más elaboradas que las del simple iusnaturalismo (al que no puede atribuirse la mejor paternidad teórica del principialismo jurídico, salvo que ese principialismo se degrade) aceptan que los principios forman parte del Derecho. Más aún, en todas esas teorías se relacionan, aunque con diferente grado de intensidad, los principios jurídicos con los institutos jurídicos, como ya lo hiciera desde el primer momento Savigny (...)". Aragón, M, "La eficacia jurídica del principio democrático," Revista Española de Derecho Constitucional, No. 24, Año 8, Madrid, septiembre-diciembre de 1998, p. 10.

48 Boввı, N, Contributi..., op. cit, p. 263.

49 En el sentir de la profesora Veronique Champell-Desplats: "(...) Una de las claves de este misterio (el de los principios generales del Derecho) reside en el hecho de que los principios jurídicos, como el derecho en general, son objeto de dos enfoques ontológicos y metodológicos radicalmente opuestos, irreductibles el uno del otro. Aunque la atención recíproca sería la más elevada, las respuestas que aportarán unos dejarán siempre insatisfechas las expectativas de los otros. El único error frente a esta dualidad de posiciones sería, a nuestro juicio, el querer superar y conciliar lo que no puede ser, al precio de un sincretismo perjudicial para el rigor de demostraciones de pretensión científica (...)". Champeil-Desplats, V, "Production et sens des príncipes: relecture analytique", Diritto ed Questioni Pubbliche, Palermo, 2012, p. 1.

50 Boввı, N.Contributi..., op. cit, p. 273. 
El Derecho es, esencialmente, un fenómeno de orden que se construye históricamente y que se manifiesta de forma profusa. Normativiza conductas, expresa y consagra valores ${ }^{51}$ a la vez que declara principios, los cuales tienen una existencia objetiva, racional y demostrable científicamente. En consecuencia, el jurista, auxiliándose de la metodología adecuada, puede identificar los órdenes sociales y morales que configuran la proyección deontológica de lo jurídico en una época determinada, esto es, su deber ser en pos de la consecución de la justicia. Toma sentido entonces lo defendido en las notas históricas, donde se amparaba la noción de los principios como componentes fundantes ${ }^{52}$ de los ordenamientos jurídicos y como guías certeras de legitimación y optimización de los mandatos que estos contienen. Sobre estos dos particulares, a saber, la legitimación y la optimización en el despliegue de los principios, merece la pena traer los razonamientos de dos connotados autores.

Ronald Dworkin comenzaba su análisis sobre la base de la siguiente distinción: "(...) en la mayoría de los casos usaré el término principio en sentido genérico, para referirme a todo el conjunto de los estándares que no son normas (...) en ocasiones seré más exacto y distinguiré entre principios y directrices políticas (...) Llamo principio a un estándar que ha de ser observado, no porque favorezca o asegure una situación económica, política o social que se considera deseable, sino porque es una exigencia de la justicia, la equidad o alguna otra dimensión de la moralidad (...)".53

51 Cfr. Peces-Barba, G, Los valores superiores, Madrid, Editorial Tecnos, S.A, 1984, pp. 47-114.

52 Para Miguel Reale: “(...) ciñéndonos al aspecto lógico de la cuestión, podemos afirmar que los principios son verdades fundantes de un sistema de conocimiento, admitidas como tales por ser evidentes, por haber sido comprobadas, y también por motivos de orden práctico de carácter operacional, o sea, como presupuestos exigidos por las necesidades de investigación y de praxis (...)". ReALE, M, Introducción al Derecho, Madrid, Editorial Pirámide, S.A, 1982, p. 139.

53 Dworkin, R, Los derechos en serio, Traducción de Marta Gustavino, Barcelona, Editorial Bosch, 1984, p. 72. 
Por su parte Robert AleXY dejaba sentado que: “(...) El punto decisivo para la distinción entre reglas y principios es que los principios son normas que ordenan que algo sea realizado en la mayor medida posible, dentro de las posibilidades jurídicas y reales existentes. Por lo tanto, los principios son mandatos de optimización, que están caracterizados por el hecho de que pueden ser cumplidos en diferente grado y que la medida debida de su cumplimiento no sólo depende de las posibilidades reales, sino también de las jurídicas. El ámbito de las posibilidades jurídicas es determinado por los principios y reglas opuestos (...)". ${ }^{54}$

En medida no despreciable, las opiniones de Dworkin y AleXY han marcado los debates actuales sobre los principios generales del Derecho, ${ }^{55}$ dando cabida a dos tendencias, una esencialista a través de la diferenciación con las reglas, y otra teleológica, que, una vez radicalizada esta distinción, los entiende como proposiciones que prescriben que algo debe realizarse en la medida de lo posible. Sobre estas cuestiones se volverá un poco más adelante, no sin antes mostrar algunas reflexiones de carácter general.

\footnotetext{
54 Alexy, R, Teoría de los derechos fundamentales, Traducción de Ernesto Garzón Valdés, Madrid, Centro de Estudios Constitucionales, Madrid, 1993, p. 86. Un poco más adelante acotaba AlEXY que: "(...) Los principios ordenan que algo debe ser realizado en la mayor medida posible, teniendo en cuenta las posibilidades jurídicas y fácticas. Por lo tanto, no contienen mandatos definitivos sino sólo prima facie. Del hecho de que un principio valga para un caso no se infiere que lo que el principio exige para este caso valga como resultado definitivo. Los principios presentan razones que pueden ser desplazadas por otras razones opuestas. El principio no determina como ha de resolverse la relación entre una razón y su opuesta. Por ello, los principios carecen de contenido de determinación con respecto a los principios contrapuestos y las posibilidades fácticas (...)". Alexy, R, op. cit, p. 99. De este mismo autor vid, "Sistema jurídico, principios jurídicos y razón práctica," Revista Doxa, No. 5, Alicante, 1988, pp. 139-151. Disponible en www.cervantesvirtual.com.
}

55 Para VIgo: "(...) Uno de los aportes más importantes de autores como AleXY o DworkIN es haber batallado con éxito en contra de las visiones exclusivamente normativistas del derecho, valiéndose para ello de los principios. Estos están en el derecho sin necesidad de test de origen o pedigree (DWORKIN) y son mandatos de optimización (AlEXY) en tanto mandan la mejor respuesta posible a tenor de las posibilidades fácticas y jurídicas que se den en el caso (...)". Vigo, R. L, De la Ley al Derecho, México DF, Editorial Porrúa, 2012, p. 267. 
Como todo fenómeno de configuración social, el Derecho se expresa, y puede ser entendido, desde enfoques generales y particulares, no perdiendo de vista que la integración y concordato de los resultados de estos enfoques intelectivos es indispensable, pues reafirma el carácter de sistema del mismo, configura su unidad y coherencia epistémica y lo consagra como unidad lógica homogénea. Ahora bien, la observancia que necesariamente debe existir entre las construcciones generales y particulares ab intra del Derecho no supone una jerarquía rígida de desprendimiento en el razonamiento, es decir, no es la unilateralidad sino la bilateralidad la que caracteriza el proceso constructivo. Así, la conectividad lógica de la ordenación jurídica se puede fundamentar tanto, descendiendo de un elemento general hacia uno particular, como ascendiendo de uno particular a uno general. Radica en este pendiente la auténtica dialéctica del saber jurídico, conjugando los ejercicios de concreción y deducción, respectivamente, en la aprehensión de la ciencia del Derecho. Este razonamiento compete a la perspectiva epistemológica, donde la reciprocidad del nexo entre lo general y lo particular no quiebra el sentido de los postulados lógicos, pues, como ha de suponerse, la perspectiva metodológica, utilizada en las estrategias de enseñanza, exige una consecuencia relacional más estricta $(v$. gr, el conocimiento cabal de la actividad de policía supone un conocimiento general sobre el funcionamiento de la Administración Pública y la finalidad de sus actuaciones).

En cierta medida, esta concepción global es la que late en la diferenciación (en atención al grado) que propone Dworkin, entre las reglas y los principios como base de su crítica al positivismo. En este sentido, los principios comparten un carácter genérico superior (orientan, no brindan instrucciones exactas de lo que hay que hacer en cada caso) al de las reglas (rules), pues no tienen claramente establecidas sus condiciones de aplicación, cuestión que por naturaleza contienen las reglas, al menos potencialmente, dado que estas requieren una decodificación a través de la interpretación que salve la vaguedad o ambigüedad 
del lenguaje normativo. Ahora bien, según el sucesor de $\mathrm{HART}^{56}$ en Oxford, el proceso creativo en la dinámica de las reglas y los principios es de doble sentido, esto es, se pueden crear reglas sobre la base de principios, y principios sobre la base de reglas ya existentes que sinteticen la orientación, alcance y sentido normativo de las mismas.

La importancia de este pensamiento no radica, obviamente, en su pretendida novedad, pues como ha quedado demostrado el tratamiento de los principios generales es mucho más antiguo. Su relevancia más notable gravita en atacar los fundamentos de la teoría del Derecho de arraigo en los estudios occidentales del momento y que de alguna forma se refleja en los casos ya vistos (Pérez Luño, Hernández Marín, Prieto Sanchís). Así, tanto la negación de Kelsen como consecuencia de su teoría pura, ${ }^{57}$ como la enarbolada por Alchourrón y Bulygin, que los entienden como meras normas no coactivas (indistinguibles de las reglas), caracterizadas por la generalidad o indeterminación semántica de las propiedades relevantes del caso o, en peor situación, como enunciados sin ningún valor para el sistema normativo, ${ }^{58}$ realzan la teoría de Dworkin, insertándola en un debate, no concluido, que intenta situar en su lugar preciso a los principios generales del Derecho.

\footnotetext{
56 Según la apreciación de HART, “(...) En cualquier grupo grande el principal instrumento de control social tiene que consistir en reglas, pautas o criterios de conducta y principios generales, y no en directivas particulares impartidas separadamente a cada individuo. Si no fuera posible comunicar pautas generales de conducta, que sin necesidad de nuevas instrucciones puedan ser comprendidas por multitudes de individuos como exigiéndoles cierto comportamiento en ocasiones determinadas, no podría existir nada de lo que hoy reconocemos como derecho. De allí que éste tenga que referirse en forma predominante, aunque no exclusiva, a clases de personas y a clases de actos, cosas y circunstancias; y su funcionamiento eficaz sobre vastas áreas de la vida social depende de que haya una capacidad ampliamente difundida para ver en los actos, cosas y circunstancias particulares, ejemplos de las clasificaciones generales que el derecho efectúa (...)". HART, H. L. A, El concepto de Derecho, Traducción de Genaro R. CARRIó, Buenos Aires, Editorial Abeledo-Perrot, 1961, p. 155.
}

57 Cfr. Kelsen, H, Teoría general..., op. cit, p. 125.

58 Apud Alchourrón, C. E. y E. Bulygin, op. cit, pp. 124-130. 
En estos razonamientos genéricos están los cimientos de las variadas aproximaciones que constatan el carácter policromático del tema. Acercamientos que parten de asegurar la existencia de los principios generales pero que difieren en la delimitación de sus contornos y la identificación precisa de su contenido en atención a su estructura lexical, lo que ha suscitado en algún sector de la doctrina la idea de sustituir el término principios por el de enunciados calificados de principios, ${ }^{59}$ significación que se comparte por entender que puede tributar a la figuración dinámica del tópico, advirtiendo que bajo ningún criterio esto supone caer en posicionamientos relativistas.

La doctrina francesa, en voz de Franck Moderne, hace eco de la sistematización realizada por WROBLESKI en su Dictionnaire encyclopédique de théorie et de sociologie du droit, así, los principios generales del Derecho pueden encontrar cabida en las siguientes tipologías: ${ }^{60}$

- Los principios positivos del derecho: normas explícitamente formuladas en los textos de derecho positivo, o al menos construidas a partir de los elementos contenidos en estas disposiciones.

59 Cfr. Champell-Desplats, V, op. cit, p. 6. También se ha impuesto en algún sector de la doctrina europea la sustitución del adjetivo generales por el de directores. Esta peculiaridad traspasa la intencionalidad semántica y se introduce en el campo de geopolítica jurídica, entendiéndose a los principios directores como aquellos que concentran el tronco común del Derecho Comunitario. Se realza así la historia y los valores políticos y culturales compartidos por las naciones en cuestión, tal y como se desprende del artículo F, párrafo 1 del Tratado de Amsterdam, donde se establece que: "( ... La Unión está fundada sobre los principios de la libertad, de la democracia, del respeto de los derechos del hombre y de las libertades fundamentales, como también en el Estado de derecho, principios supraconstitucionales, susceptibles de irrigar a la vez la Unión Europea y los Estados miembros, sobre bases que no sean exclusivamente económicas, sino más bien políticas (...)". Sin lugar a dudas esta realidad requiere de mecanismos de armonización que posibiliten la supremacía del ius comunitatis y la efectiva competencia de las Cortes Europeas. En consonancia, Chueca Sancho ha dicho que: "( ...) a través de los principios generales: "(...) se mantiene la progresión y la coherencia del ordenamiento comunitario. Coherencia que aseguran firmemente (a) los principios fundamentales de la Comunidad Europea (...)". CHueCA Sancho, A. G, "Los principios generales del derecho en el ordenamiento comunitario," Revista de Instituciones Europeas, No. 3, Vol. 10, septiembre-diciembre de 1983, p. 868.

60 Cfr. Moderne, F, op. cit, pp. 26-27. 
- Los principios implícitos del derecho: reglas tratadas como premisas o consecuencias de las disposiciones del derecho positivo, sin estar ahí expresamente enunciadas.

- Los principios extrasistémicos del derecho: reglas consideradas como principios, pero que no pueden ser ordenadas en las dos primeras categorías, pues son exteriores al derecho positivo.

- Los principios-nombres del derecho: denominaciones sin carácter normativo que caracterizan los rasgos esenciales de una institución jurídica.

- Los principios-construcciones del derecho: instrumentos conceptuales propuestos para la elaboración dogmática del derecho o en la aplicación y la interpretación jurídica.

Si bien este esfuerzo de acopio tiene como objetivo fundamental mostrar el carácter polisémico del término, lo que redunda en un colorido conceptual, lo cierto es que deviene en prototipo del tratamiento que, en observancia de su existencia $\mathrm{u}$ operatividad, han merecido los principios generales en las diferentes escuelas de pensamiento filosófico-jurídico. Resulta curiosa la tercera clasificación, pues en cierta medida es ajena a la idea de vinculación jurídica en clave principalista, dado que se limita a factores descriptivos y caracterizadores de determinadas figuras, siendo equivalente, desde una perspectiva práctica, a la afirmación de la inexistencia de estos.

Los trabajos de los autores alemanes, sobre todo Esser y LARENZ, prestan especial atención a la diferenciación y relación existente entre los principios de Derecho positivo y los principios de Derecho justo. El primero de los tratadistas defiende la existencia de principios de Derecho positivo que, por una parte, subyacen en una regulación legal, y por otra, se hacen valer en la jurisprudencia sin importar que resulten, a primera vista, desconocidos o inmersos en fundamentaciones aparentes. Así, en su diferenciación de los principios con las normas entiende a los primeros como insuficientes para constituir por sí mismos 
un mandato, pues su rol es el de ser la base, el criterio o la justificación misma de dicho mandato. ${ }^{61}$

LARENZ, después de afirmar que: "(...) los principios no son cabalmente reglas acabadas (...) pues son (...) los fundamentos iniciales de una regulación, que pueden recibir concreción de diferente modo en una regulación intelectualmente fundada en ellos (...) es sólo el primer paso en la consecución de una regulación, al cual tienen que seguir después otros (...), ${ }^{62}$ se pregunta si todos los principios de Derecho positivo son principios de Derecho justo, a lo que responde, con notables toques de iusnaturalismo. ${ }^{63}$

Esta idea primaria de los principios tiene un antecedente importante en la fenomenología de SchreIER, quién dedicó una obra a: "(..) buscar los principios supremos del derecho (...)". ${ }^{64}$

61 Sigue este autor, en lo que interesa a multiplicidad conceptual de los principios generales, el acercamiento de clasificación que propone Spenduti, que distingue las tipologías siguientes: Principios sistemáticos y doctrinales, así como los de la lex artis jurídica (principios científicos); Principios inmanentes de las instituciones positivas y los principios lógicos que se imponen inmediatamente al pensamiento jurídico (principios normativos); Principios de la justicia material, en tanto que no hayan recibido una incorporación positiva, y otros principios directivos o guides (principios informativos, de la política y heurísticos de la teoría); Las reglas del arte, principios de la interpretación y reglas de la prueba; Los axiomas de la lógica y la experiencia jurídicas; Las máximas y regulae iuris, de valor más didáctico que constructivo o substantivo.

62 Larenz, K, Derecho justo. Fundamentos de Ética jurídica, Madrid, Civitas Ediciones, S. L, 1985, p. 35.

63 Para este alemán: “(...) si la respuesta a esta pregunta fuera afirmativa, los principios no podrían servir como criterio para discernir si un determinado Derecho positivo está en el camino hacia la justicia y si su pretensión de validez está justificada (...); si se entiende por principios del Derecho (...) a los pensamientos directores de una regulación jurídica, es manifiesto que hay unos principios que desde el punto de vista del Derecho justo son injustos y otros que son intercambiables, de suerte que no están exigidos y son por ello en cierta medida neutrales (...)". LARENZ, K. Derecho justo..., op. cit, p. 37. En otra obra de igual calado LARENz expresó que: "( ...) los principios son formas de expresión, direcciones de movimiento, tendencias del espíritu objetivo que se abren paso en la conciencia jurídica general y encuentran su expresión en la ley y en la jurisprudencia (... I). LARENZ, K, Metodología de la ciencia del Derecho, Barcelona, Editorial Ariel, 1966, p. 326.

64 Schreler, F, Concepto y formas fundamentales del Derecho. Esbozo de una teoría formal del Derecho y del Estado sobre base fenomenológica, Traducción de Eduardo García Máynez, 
También merece este tratamiento el sociologismo de James GoLDsснміDт, que como alternativa a su polémica concepción sobre las fuentes del derecho, propuso la averiguación científica del dinamismo que lo produce. ${ }^{65}$ A su vez, el historicismo de Sternberg sirvió de savia orientadora de las aseveraciones anteriores, pues si bien parte de negar categóricamente la existencia del derecho natural, participa de una visión dinámica del fenómeno jurídico, influenciado por el ambiente en el que se realiza y contentivo de principios generales que lo definen esencialmente. ${ }^{66}$

Se observa al tenor de estas selectas referencias que el tema de los principios generales, si bien constituye un reservorio técnico, también se arropa de construcciones axiológicas (consagración y medidor de justicia) y de conceptos derivados de la moral. Esta situación, en virtud de introducir otros elementos a considerar, amplia la funcionalidad de los principios, atribuyéndole un sentido más allá de lo normativo, esto es, de guía, de ordenación, de fundamentos, lo que responde, tal y como quedó plasmado supra, a una concepción compleja y multidimensional del fenómeno jurídico genéricamente comprendido.

También resulta prudente, por su valía, rememorar las opiniones del italiano Gustavo Zagrebelsky, muy en consonancia con los criterios alemanes ya vistos. Para él la exigencia de positivación en materia de principios generales del Derecho: “(...) deriva del persistente prejuicio de pensar que, en realidad, las verdaderas

Buenos Aires, Editorial Losada, S.A, 1942, p. 29.

65 Apud GoldschmidT, J, Problemas generales del Derecho, Obra póstuma, Prólogo de Eduardo J. Couture y Nota Bio-Bibliográfica de Niceto Alcala-Zamora y Castillo, Buenos Aires, Editorial Depalma, 1944, pp. 66-67. Entiende este autor que: “(...) en realidad, la ley y el derecho consuetudinario son dos formas del derecho, pero no las fuentes del mismo. La equivocación se corrige, pero sólo formalmente, sustituyendo ley y derecho consuetudinario por el acto estatal que manda el cumplimiento de la ley (ita ius esto), o bien por la costumbre (inveterata consuetudo) que manifiesta el derecho consuetudinario. Hasta hoy día, la ciencia jurídica ha descuidado la averiguación de las verdaderas fuentes del derecho, a saber, el dinamismo que produce el derecho (...)". Goldschmidt, J, op. cit, pp. 66. También vid su concepción cultural del Derecho y de la Justicia, op. cit, pp. 16 y ss.

66 Apud Sternnerg, T, Introducción a la ciencia del Derecho, Barcelona-Madrid-Buenos AiresRio de Janeiro, Editorial Labor, 1940, S.A, pp. 20-33 y 125 y ss. 
normas son las reglas, mientras que los principios son un plus, algo que solo es necesario como válvula de seguridad del ordenamiento. Una vez más, el positivismo se revela como una ideología distorsionadora en el campo del Derecho (...)" ${ }^{67}$

Con este posicionamiento se coloca el autor en la línea defensiva de este trabajo, esto es, el rechazo de la inclinación positivista $^{68}$ en virtud de la cual los principios generales son entendidos como derivaciones normativas de segundo (o tercer) orden, llamados únicamente a salvar las falencias regulativas de la ley u otras disposiciones legales, obviando su matiz informador, su carácter de sostén y su vocación de integración del ordenamiento jurídico, además de la expresión de valores y el carácter creativo que suponen. ${ }^{69}$

67 Zagrebelsky, G, El derecho dúctil. Ley, derechos, justicia, Madrid, Editorial Trotta, 2005, p. 117. También refería este autor: “(...) Si el derecho actual está compuesto de reglas y principios, cabe observar que las normas legislativas son prevalentemente reglas, mientras que las normas constitucionales sobre derechos y sobre la justicia son prevalentemente principios. Por ello, distinguir los principios de las reglas significa, a grandes rasgos, distinguir la Constitución de la ley (...)". Zagrebelsky, G, op. cit, pp. 109-110. Esta afirmación ha sido enjuiciada en la doctrina cubana por la profesora FerRari Yaunner, quien sostuvo: "(...) Aunque este criterio ofrece un análisis interesante que sustenta el carácter informador de la Constitución con respecto a todo el ordenamiento, lo que se logra muchas veces por la cantidad de principios que en esta se enuncian, nos parece demasiado extremo el criterio del autor, ya que no es solo en la Constitución donde aparecen enunciados importantes principios (...)". Ferrari Yaunner, M, Los principios de legalidad y seguridad jurídica como fundamentos del proceso de integración del Derecho para colmar las lagunas de la ley en Cuba, La Habana, Tesis presentada en opción al grado de Doctora en Ciencias Jurídicas bajo la tutoría de la Dra. Lissette Pérez Hernández, 2010, p. 99.

68 Cfr. AlberTI, E, “El derecho por principios: algunas precauciones necesarias (Debate sobre El Derecho dúctil, de Gustavo Zagrebelsky)," Anuario de Filosofía del Derecho, Nueva Época, tomos XIII y XIV, Madrid, Centro de Publicaciones del Ministerio de Justicia, Boletín Oficial del Estado, Ministerio de la Presidencia, 1996-1997, pp. 39-44. En el mismo Anuario..., vid. Ios trabajos de Alfonso García Figueroa ("El no positivismo principalista en II diritto mite de Gustavo Zagrebelsky," pp. 87-109) y Luis Prieto SAnCHís (“El constitucionalismo de principios, ¿entre el positivismo y el iusnaturalismo? A propósito de El derecho dúctil de Gustavo Zagrebelsky," pp. 125-158).

69 También destaca en la doctrina italiana el criterio de GUASTINI, para quien el término principio puede designar los enunciados presentando: un grado de generalidad (por oposición a enunciados expresados en las normas individuales o especiales); un grado de abstracción (por oposición a los enunciados que designan las clases de elementos provistos de una 
Otra categorización interesante sobre la multiplicidad de aristas que entrañan los principios generales es la defendida por PÉREZ LuÑo. ${ }^{70}$ Este trabajo sistematizador, que ha tenido buena acogida en la doctrina española, ${ }^{71}$ resalta por su simplicidad y claridad expositiva. La visión tripartita que sostiene este autor al respecto se puede resumir en los siguientes postulados:

- Los principios generales como metanormas: se trata de lo que puede considerarse como su significado metodológico en el que aparecen entendidos como principia cognoscendi, es decir, como reglas orientadoras para el conocimiento, para la interpretación y para la aplicación de las restantes normas jurídicas. A través de este uso lingüístico los principios se consideran jurídicos por referirse al derecho, por suministrar una base lógica o técnicoformal que contribuye a la comprensión y aplicación de las normas de primer grado. Junto a esta acepción de los principios del derecho como metanormas tiene también un significado metodológico la concepción de los principios del derecho como ratio legis o mens legis de las normas, o sea, como la finalidad, objetivo o policy perseguido por las normas y que deben orientar su interpretación teleológica y evolutiva.

correspondencia identificable en el mundo físico); un carácter programático (y no prescriptivo o inmediatamente realizable); un nivel elevado en la jerarquía de las normas (legislativo, internacional, constitucional o incluso supra- constitucional); una función estructural o fundamental en el sistema jurídico o en una rama de éste; una función de selección o de interpretación de los textos aplicables a un caso. Guastinı, R, "Sui principî di diritto," Diritto e società, No. 4, Padova, 1986, p. 601.

70 Pérez luño, A. E. La seguridad..., op. cit, pp. 30 y ss.

71 Cfr. Beladiez Rojo, M, (2010). Los principios jurídicos, Madrid, Cuadernos Civitas, Thomson Reuters, 2010, pp. 39-55; y Rodríguez Boente, S. E, Los principios generales del Derecho, Santiago de Compostela, Universidad de Santiago de Compostela, 2008, pp. 43 y ss. También vid las consideraciones de Guillermo G. VaLDECASAS en su trabajo "Los principios generales del Derecho en el nuevo título preliminar del Código Civil," Anuario de Derecho Civil, Tomo XXVIII, Fascículo II, Madrid, Ministerio de Justicia y Consejo Superior de Investigaciones Científicas, abril-junio de 1975, pp. 331-336. 
- Los principios generales en sentido ontológico o como principia essendi: desde este enfoque los principios generales son invocados por el ordenamiento jurídico en calidad de fuentes normativas. Conviene advertir que en esta acepción la juridicidad de los principios obedece a su propia condición de elementos o partes integrantes del ordenamiento, que se refiere a ellos de forma expresa o tácita, ya que hay que entender que si los principios jurídicos fueran únicamente los explícitamente recogidos en los textos normativos no tendría sentido reiterar en una disposición expresa su carácter de fuente y la posibilidad de su aplicación. También poseen un sentido ontológico aquellos principios que los operadores jurídicos pueden inducir por abstracción y generalización a partir del sistema de las normas positivas; así como las máximas, aforismos o brocados de la tradición jurídica; las fuentes misteriosas a las que, en ocasiones, se atribuye la génesis del derecho a través de la historia; los principios políticos inspiradores del sistema jurídico; o las categorías formales de la dogmática que expresan la naturaleza jurídica o esencia de los conceptos jurídicos fundamentales.

- Los principios generales en dimensión axiológica: como los prima principia, axiomas o postulados éticos que deben inspirar todo el orden jurídico. En esta acepción lingüística se entiende que los principios son jurídicos porque el derecho se remite a ellos como término o canon de aspiración (así, cuando las normas apelan a principios que expresan las exigencias básicas de los valores de la justicia, el bien común, la moralidad, o el ethos social); o bien porque se considera que deben ser parte integrante del ordenamiento jurídico de un Estado de derecho.

Si bien, como ya quedó expuesto, no se comparte la directriz de este autor al entender a los principios generales como mitos jurídicos, justo es decir que el anterior ejercicio de síntesis de perspectivas resulta muy atinado, pues en él se exponen, 
aunque sea para mostrar lo defendido por diversos autores de forma unilateral, los diferentes cauces deductivos que, desde una visión compleja, se deben tomar en consideración para estructurar un concepto unitario y coherente con la variedad de funciones que juegan los principios generales en los diversos planos de la ciencia jurídica. Sobre estos cauces categoriales se construirán los razonamientos que siguen.

\section{Principios, valores y reglas. Nociones distintivas}

Después de haber realizado un recorrido por representativos posicionamientos doctrinales, resulta sensato dejar sentando que los principios generales del Derecho se resisten a una conceptualización esquemática, esto es, que no contenga en sus límites las variadas condicionantes y las disímiles manifestaciones que estos pueden presentar. $^{72}$

Con palabras no muy amables, el italiano Emilio BeтTI refería esta cuestión aduciendo que a la ripugnanza che $i$ principi generali oppongono a una precisa formulazione. ${ }^{73} \mathrm{~A}$ simili, Georges Morange se proyectaba aseverando que: "(...) faire référence aux principes généraux $d u$ droit, c'est faire référence à un concept qui, au fils des ans, est devenu de plus en plus ambigu. (...)". ${ }^{74}$ Mientras que Bueno, con enfoque filológico,

72 Comentó Spota que estos son: "(...) principios que reciben una aplicación general en la jurisprudencia, en la doctrina, en las legislaciones universales. La disociación entre la ley y la vida del derecho, entre la norma escrita y la costumbre o la práctica, y que surge con las innovaciones económicas, sociales, políticas, etc.; el progreso de la técnica; la circunstancia de que el derecho no es algo invariable; la perfección misma de la idea de justicia; todo ello va tornando en imperativo la necesidad de adecuar la ley a la vida, a la realidad social, a las transformaciones que acaecen (...)". SpotA, A. G, Tratado de Derecho Civil, tomo I, Parte General, Vol. I. Introducción. Concepto del Derecho. Teoría de la Institución. Función de la Doctrina. Jurisprudencia y Costumbre, Buenos Aires, Editorial Depalma, 1947, pp. 385-386.

73 BetTI, E, Interpretazione della legge e degli atti giuridice (Teoria generale e dogmatica), Milano, Dott. A. Giuffré-Editore, Milano, 1949, p. 208.

74 Morange, G, "Une catégorie juridique ambiguë: les príncipes généraux du droit," Revue de Droit Public et de la Science Politique en France et a l'étranger, No. 4, Juillêt-Août, París, Librairie Générale de Droit et de Jurisprudence, 1977, p. 761-762. Vid también en la doctrina 
alertaba sobre el peligro de la expresiones en genitivo, siempre tendentes a la ambigüedad interpretativa, ${ }^{75}$ situación que perfectamente se aplica al objeto de estudio de estas líneas, pues la locución principios del Derecho puede hacer referencia a la existencia de principios propios del Derecho o al influjo de principios extrajurídicos en este saber, ${ }^{76}$ esto sin restar atención a la complicada connotación lingüística, ya referida, del término de adjetivación generales.

Lo primero a resaltar para el entendimiento cabal de la categoría tratada es el ya aludido combate a la salida positivista. ${ }^{77}$ El reconocimiento de la existencia y el valor operativo de los principios generales del Derecho, no solamente como fuente supletoria, sino como criterios de justificación e interpretación de las normas jurídicas en general, afecta el entendimiento del Derecho (como construcción científica) ${ }^{78}$ y su funcionamiento mismo, tanto en lo que interesa a su sentido ético, ${ }^{79}$ como en su

francesa a Boulanger, "Principes généraux du Droit et Droit positif," Le Droit Privé Français au milieu du XXe siècle. Etudes offertes ò Georges Ripert, tome I, Etudes générales. Droit de la famille, Paris, Libraire générale de Droit et jurisprudence, 1950, pp. 51-74; Chapus, R, "De la valeur juridique des principes généraux du droit et des autres règles jurisprudentielles du droit administratif," Recueil Dalloz. Sirey de doctrine, de jurisprudence et de législation, Paris, Jurisprudence Générale Dalloz, 1966, pp. 22 y ss; JeannEAU, B, "La théorie des principes généraux du droit a L'épreuve de temps," Études et Documents, Paris, Conseil de État, 19811982, pp. 33 y ss.

75 Bueno, G, ¿Qué es la filosofía? Oviedo, Editorial Pentalfa, 1995, p. 41.

76 Al respecto vid el interesante estudio de Atienza, M. y J. Ruiz Manero, op. cit, pp. 101-120. También consultar Carrió, G. R, Notas sobre Derecho y lenguaje, Buenos Aires, Editorial Abeledo-Perrot, 1986, in integrum.

77 Apud Guiboung, R. A, Saber Derecho, Buenos Aires, Editorial Abeledo-Perrot, S.A, 2013, pp. 200-206.

78 Según Miguel Reale: "(...) toda forma de conocimiento filosófico y científico implica la existencia de principios, es decir, de ciertos enunciados lógicos que se admiten como condición o base de validez de las demás afirmaciones que constituyen un determinado campo del saber (...)". Reale, M, op. cit, p. 139.

79 Apud Gascón Abellán, M. y A. García Figueroa, La argumentación en el Derecho. Algunas cuestiones fundamentales, Lima, Editorial Palestra Editores, 2003, pp. 218 y ss. En opinión de los administrativistas españoles Eduardo García de Enterría y Tomás-Ramón Fernández: "(...) Los principios generales del Derecho expresan los valores materiales básicos de un 
alcance regulador propiamente dicho, que debido al papel que estos desempeñan no coincide con el ámbito circunscrito por el derecho positivo en sentido estricto. ${ }^{80}$

El contenido de estos, que en última instancia es un reflejo de las ideas rectoras que transversalizan la esencia de las interacciones dentro un grupo social organizado, se encuentra en íntima relación con los caracteres del contexto cultural en el que se insertan y también responde a los condicionamientos históri$\cos .{ }^{81}$ Se impone un encausamiento sociológico de los principios generales del Derecho, en virtud del cual sean entendidos como un producto de la cultura, ${ }^{82}$ no resultante de la voluntad del aparato estatal, ni de los usos reiterados, sino como un sentimiento

ordenamiento jurídico, aquellos sobre los cuales se constituye como tal, las convicciones ético-jurídicas fundamentales de una comunidad. Pero no se trata simplemente de unas vagas ideas o tendencias morales que puedan explicar el sentido de determinadas reglas, sino de principios técnicos, fruto de la experiencia de la vida jurídica y sólo a través de ésta cognoscibles (...)". García de Enterría, E. y T. R. Fernández, Curso de Derecho Administrativo I, Madrid, Editorial Civitas, 2011, pp. 89-90.

80 Cfr. Saavedra López, M, 14 lecciones de Teoría del Derecho, Granada, Departamento de Filosofía del Derecho de la Universidad de Granada, 2011, pp. 131 y ss. En sintonía con este autor se encuentra la definición ofrecida por LATORRE: "(...) los enunciados generales a los que se subordina un conjunto de soluciones particulares. Son, en consecuencia, los fundamentos mismos del sistema jurídico a partir de los cuales se despliega todo el aparato de las normas (...)". Latorre, A, Introducción al Derecho, Barcelona, Editorial Ariel, 1991, p. 65.

81 El profesor Fernández Bulté defendió en este sentido que los principios generales han de entenderse como: "(...) ciertas reglas, postulados, fundamentos y apoyaturas esenciales de un sistema jurídico determinado, los cuales son también condicionados históricamente, cambiantes y en pleno y constante desarrollo (...)". Fernández Bulté, J, Teoría del Estado y del Derecho. Teoría del Derecho, La Habana, Editorial Félix Varela, 2009, p. 234.

82 Ross analizó esta cuestión centrándose en la labor del juez: “( . . ) cuán poco realista es ese tipo de positivismo jurídico que limita el derecho a las normas puestas por las autoridades y que cree que la actividad de juez sólo consiste en una aplicación mecánica de ellas (...), en el cumplimiento de su misión se halla bajo la influencia de la tradición de cultura porque es un ser humano de carne y hueso y no un autómata, o mejor dicho, porque el juez no es un mero fenómeno biológico sino también un fenómeno cultural. El ve en su actividad una tarea al servicio de la comunidad. Desea hallar una decisión que no sea el resultado fortuito de la manipulación mecánica de hechos y parágrafos, sino algo que tenga un propósito y un sentido, algo que sea válido. La tradición de cultura adquiere primordialmente significado porque el juez lee e interpreta el derecho en su espíritu (...)". Ross, A, Sobre el derecho y la justicia, Traducción de Genaro R. CarRió, Buenos Aires, Editorial Eudeba, 1970, p. 96. 
jurídico de carácter universal que la propia dinámica social arroja y legitima, creándose consenso sobre su óptima funcionabilidad en determinado sistema jurídico. ${ }^{83}$ Corresponde a la doctrina y a la jurisprudencia, ${ }^{84}$ a modo de correlato, identificar dichos sentimientos en pos de que sean tomados en cuenta por el legislador en su labor ordenadora, tanto como sustentadores de toda la estructuración positiva, como en su condición de fuente de Derecho.

En este orden de ideas, se entiende que los principios generales del Derecho requieren para su configuración, al menos potencialmente, de una actividad creativa del jurista. Es decir, son normas jurídicas marcadas por la abstracción, entendidas estas en la bifurcación de reglas y principios, pues, lógicamente, de ellos se derivan formas de actuación a seguir y pautas a cumplimentar para la encomiable realización de la ordenación jurídica. En el ordenamiento jurídico pueden aparecer explícitamente o implicitamente, siendo necesaria en este último caso la interpretación que lo extraiga de los enunciados presentes en el mismo. ${ }^{85}$

Llegado el análisis a este punto, salta una interrogante cuya certera respuesta es ineludible: ¿Qué relación y que diferencias existe entre los principios y los valores?

83 Para Diez-Picazo y Gultón: “(...) A los principios generales del Derecho, quien los dota de valor es la convicción social, que es quien los crea y quien en definitiva los mantiene (...)". Diez-Picazo, L y A. Gullón, Sistema de Derecho Civil, Vol. I, Madrid, Editorial Tecnos, S.A, 1989, p. 165.

84 Apud Clavero Arévalo, M. F, "La doctrina de los principios generales del Derecho y las lagunas del ordenamiento administrativo," Revista de Administración Pública, Año III, No. 7, Madrid, Instituto de Estudios Políticos, Madrid, enero-abril de 1952, pp. 60 y ss.

85 Se comparte el criterio de BoвBı sobre este pendiente: “(...) Dos son los argumentos para sostener que los principios generales son normas, y ambos son válidos: de acuerdo con el primero de ellos, si son normas aquellas que se extractan de los principios generales por medio de un procedimiento de generalización sucesiva, no se ve por qué éstos no deban ser normas también (de las especies animales obtengo siempre animales y no flores o estrellas). En segundo lugar, la función para la cual se deducen y se adoptan es la misma que se lleva a cabo para todas las normas, o sea, la función de regular un caso. ¿Con qué fin se deducen en caso de laguna? Es claro que para regular un comportamiento no regulado (...)". BoвBı, N, Teoría general del Derecho, Madrid, Editorial Debate, S.A, 1998, p. 251. 
La complejidad de la respuesta estriba de un pendiente de lógica conceptual, pues como ya se ha dicho, los principios generales del Derecho también son contentivos de manifestaciones éticas, más si se participa de establecer una sinonimia entre estos y los contornos del derecho natural, entendidos como los constantes movimientos valorativos de la experiencia jurídica. ${ }^{86}$

En un análisis que se realice desde un plano de abstracción considerable, los principios y los valores pueden aparecer como realidades fenoménicas idénticas, pues, como dijera AlExy, “(...) el cumplimiento gradual de los principios tiene su equivalente en la realización gradual de los valores (...)". ${ }^{87}$ No obstante, desde el mundo jurídico se abre una diferencia infranqueable, a saber: los principios generales del Derecho son normas jurídicas que, aunque con sus peculiaridades, suponen una actividad conductual sujeta a un grado de vinculación más o menos efectivo. ${ }^{88}$ Los valores, en cambio, son realidades sociales que, más que prescribir, identifican como acertada o desacertada una situación social dada en atención a determinada moral media. ${ }^{89}$ Ahora bien, esto no significa que a través de un principio no se pueda realizar un valor, como muestra de la conectividad compleja de la que participa el Derecho en las inclinaciones sociales.

ALEXY llega a una conclusión similar tomando como sustrato analítico la diferenciación de los conceptos prácticos establecida por vON WRIGHT. Así, considerando la existencia de conceptos prácticos deontológicos, axiológicos y antropológicos, queda

\footnotetext{
86 Apud Beladiez Roso, M, op. cit, pp. 57 y ss.

87 Alexy, R. Teoría de los..., op. cit, p. 138.

88 Un análisis profundo sobre las normas jurídicas en Aftalion, E. R, op. cit, pp. 19 y ss.

89 Un criterio en contrario fue defendido por Peces-BarBa. En su análisis del artículo 1.1 de la Constitución española de 1978, contentivo de los valores superiores, este autor sostuvo que: "(...) tanto los valores superiores como las diferentes referencias a principios que se hacen en la Constitución se sitúan en el ámbito de las normas. Es decir, no estamos aquí ante una forma de Derecho distinta de las normas como pretende Dworkin, sino que son expresiones que, con su significado, forman parte del contenido de unas normas del Derecho positivo español (...)". Peces-Barba, G. Los valores..., op. cit, p. 36. También se pronunció en un sentido similar Beladiez Roso, M, op. cit, pp. 101-127.
} 
esclarecido que los principios, en tanto mandatos de un determinado tipo, esto es, de optimización, pertenecen al grupo conceptual deontológico, en virtud de materializarse en ellos el concepto deóntico fundamental de mandato o de deber ser. Los valores, por su parte, integran el grupo conceptual axiológico, pues su naturaleza se construye a partir del concepto fundamental de lo bueno. ${ }^{90}$

Se puede agregar igualmente el grado diferenciado de objetivación que unos y otros presentan. La amplitud de los valores expresan mayores ataduras subjetivas, pues la condición de que un objeto o comportamiento social sea valorado de tal o más cual manera, supone la determinación de un concepto sujeto a ondulaciones histórico-culturales. ${ }^{91}$ Lo mismo ocurre con los principios. No obstante, la vinculación de estos últimos con una realidad técnica innegable y la circunscripción precisa de su

90 Apud Alexy, R. Teoría de los..., op. cit, pp. 139-141. Un poco más adelante puntualizaba este autor que: "(...) La diferencia entre principios y valores se reduce así a un punto. Lo que en el modelo de los valores es prima facie lo mejor es, en el modelo de los principios, prima facie debido; y lo que en el modelo de los valores es definitivamente lo mejor es, en el modelo de los principios, definitivamente debido. Así pues, los principios y los valores se diferencian sólo en virtud de su carácter deontológico y axiológico respectivamente. En el derecho de lo que se trata es de qué es lo debido. Esto habla en favor del modelo de los principios. Por otra parte, no existe dificultad alguna en pasar de la constatación de que una determinada solución es la mejor desde el punto de vista del derecho constitucional a la constatación de que es debida iusconstitucionalmente. Si se presupone la posibilidad de un paso tal, es perfectamente posible partir en la argumentación jurídica del modelo de los valores en lugar del modelo de los principios. Pero, en todo caso, el modelo de los principios tiene la ventaja de que en él se expresa claramente el carácter de deber ser. A ello se agrega el hecho de que el concepto de principio, en menor medida que el de los valores, da lugar a menos falsas interpretaciones. Ambos aspectos son lo suficientemente importantes como para preferir el modelo de los principios (...)". AlexY, R, op. cit, p. 147.

91 Cfr. García Máynez, E, Ética. México DF, Publicaciones del Centro de Estudios de Filosofía de la Universidad Nacional de México, Colección de Manuales Escolares, No. I, 1944, pp. 97 y ss. En el espacio específico de lo jurídico vid, Basave Fernández del Valle, A, Filosofía del Derecho. Fundamentos y proyecciones de la filosofía jurídica, México DF, Editorial Porrúa, 2011, pp. 687 y ss; Parejo Alfonso, L, “Los valores en la jurisprudencia del Tribunal Constitucional," Libro Homenaje al profesor José Villar Palasi, Madrid, Editorial Civitas, S.A, 1989, pp. 923 y ss; y Parejo Alfonso, L, "Constitución y valores del ordenamiento," Estudios sobre la Constitución española. Homenaje al profesor Eduardo García de Enterría, tomo I. Ordenamiento jurídico, Madrid, Editorial Civitas, S.A, 1991, pp. 29 y ss. 
operatividad jurídica, los hace menos vulnerables a las apreciaciones subjetivadas.

Como ejemplo de la importante relación existente entre principios y valores se puede referir el auxilio de estos segundos en caso de concurrir una colisión de los primeros. La solución más coherente y eficiente a esta situación radica en la ponderación de un principio con respecto al otro, ${ }^{92}$ configurándose lo que se ha dado a llamar en la doctrina jerarquía axiológica móvil. ${ }^{93}$

Así, a través de un juicio valorativo del intérprete, que se encuentra ante la posibilidad aplicativa de dos principios que resultan contrapuestos, uno de los principios es ponderado, esto es, se le atribuye un peso mayor con respecto al otro. No obstante, vale aclarar que este supuesto de descarte de un principio a favor de la aplicación de otro no es una operación estática. Al ser un juicio de valor el criterio determinante, cabe perfectamente la posibilidad de que el principio ponderado resulte ser el descartado al variar cualquiera de las circunstancias operantes en el primer caso. Es por este motivo que la ponderación axiológica de un principio con respecto al otro no puede realizarse en abstracto. Sólo las peculiaridades concretas de la situación fáctica pueden justificar la actuación al respecto del intérprete. ${ }^{94}$

\footnotetext{
92 Apud Alexy, R. Teoría..., op. cit, pp. 89 y ss.

93 Apud Alexy, R. Teoría.... op. cit, pp. 90 y ss; y Guastini, R, Estudios de teoría constitucional, México DF, Editorial de la UNAM, Distribuciones Fontamara, Colección de Doctrina Jurídica Contemporánea, 2001, pp. 145-147. GuAstinı ha explicado que: “(...) Una jerarquía axiológica es una relación de valor instituida (no por las mismas fuentes, sino) por el intérprete, precisamente mediante un subjetivo juicio de valor. Instituir una jerarquía axiológica consiste en atribuir a uno de los dos principios en conflicto mayor peso, es decir, mayor valor, respecto del otro. El principio dotado de mayor valor prevalece, en el sentido de que es aplicado; el principio axiológicamente inferior sucumbe -no en el sentido de que resulte inválido 0 abrogado, sinoen el sentido de que se deja de lado (...)". Guastinı, R, Estudios..., op. cit, p. 145.

94 Agrega GuASTINI que: “(...) Una jerarquía móvil, por otra parte, es una relación de valor inestable, mudable, que vale para el caso concreto, pero que podría invertirse en relación con un caso concreto diverso. En efecto, para instituir esta relación jerárquica, el juez no sopesa el valor de dos principios en abstracto y de una vez por todas, sino que valora el posible impacto de su aplicación al caso concreto. Si el resultado que tendría en el caso concreto la aplicación del principio P1 parece más justo (o menos injusto) que el resultado que tendría
} 
En lo que compete a las notas diferenciales entre los principios y las reglas, las aportaciones doctrinales con más virtualidad pueden agruparse en dos grandes sectores, a saber:

- La diferenciación entre reglas y principios se localiza en la peculiar estructura lógica de estos últimos. Así, las reglas serían normas hipotéticas, que conectan precisas consecuencias a no menos precisos (clases de) supuestos de hecho; en cambio, los principios serían normas incondicionadas, es decir, carentes de supuesto de hecho, o, en cualquier caso, con supuesto de hecho abierto, de manera que su campo de aplicación quedaría totalmente indeterminado.

- La diferenciación entre reglas y principios no depende de su contenido normativo, sino, sobre todo, de la posición peculiar que estos últimos ocupan en el ordenamiento jurídico (o en uno de sus subsectores). Así, los principios serían normas fundamentales, caracterizadoras, que confieren identidad axiológica al ordenamiento (o a uno de sus subsectores) y ofrecen justificación a las restantes normas (del ordenamiento en su conjunto o de ese particular subsector). ${ }^{95}$

Se observa que de un lado se pondera el aspecto formal, esto es, el alcance y la forma estructural misma de la norma. En otro sentido, lo que se realza como aspecto diferenciador compete al contenido, es decir, la materia que se conjuga y lo que ésta representa para el orden jurídico. Cabe entonces preguntarse si la forma y la materia de un mismo fenómeno no pueden englobarse en una misma construcción teórica. ¿Acaso

\footnotetext{
la aplicación del principio P2, entonces, en el caso concreto, se prescindirá del principio P2, mientras que, en el caso concreto, se aplicará el principio P1. Pero téngase en cuenta "en el caso concreto". Nada impide que, en caso diverso, sea la aplicación de P2 la que tenga resultados que se consideren más justos (o menos injustos) que la aplicación de P1, y que, por tanto, la relación jerárquica resulte invertida, aplicando P1 y prescindiendo de P2. En este sentido, pues, se trata de una jerarquía móvil: si en un caso se ha atribuido mayor peso o valor a P 1, nada impide que en un caso diverso se atribuya mayor peso o valor a P2 (...)". GuastinI, R. Estudios..., op. cit, p. 146.

95 Guastinı, R. Estudios..., op. cit, p. 133.
} 
forma y contenido no se presentan como un desdoblamiento de una misma realidad?

Ahora bien, en consonancia con lo hasta aquí defendido, es coherente, en lo que interesa a la distinción entre principios y reglas ${ }^{96}$ asumir la teoría teleológica de Alexy, ya delineada por Dworkin, ${ }^{97}$ consistente en entender a los primeros, en su sentido de directriz y cánones programáticos del ordenamiento jurídico, como mandatos de optimización. En este sentido, a diferencia de las reglas (que se aplican al modo de todo o nada), los principios pueden ser cumplidos en grados diferenciados, pues ellos atienden a posibilidades jurídicas y no fácticas, dado que no proporcionan las consecuencias que se derivan automáticamente de la realización de condiciones previamente determinadas.

Las cuestiones generales analizadas han de ser atendidas a los fines de determinar la función de los principios generales del Derecho en la realidad jurídica, asunto que será examinado supra, no sin antes presentar algunas notas sobre el estado del arte a la luz de las polémicas iusfilosóficas.

\section{Naturalismo y positivismo en la fundamentación iusfilosófica de los principios generales del Derecho}

Aunque un poco más arriba han quedado expuestas algunas pautas que enmarcan la construcción de los principios generales del Derecho en observancia de la directriz iusnaturalista,

\footnotetext{
96 Apud Braithwaite, J, "Rules and Principles: A Theory of Legal Certainty," Australian Journal of Legal Philosophy, No. 27, 2002, pp. 50-52.

97 Para Dworkin la diferencia: “(...) es una distinción lógica. Ambos órdenes de normas señalan decisiones concretas sobre obligaciones legales en circunstancias determinadas, pero difieren por el carácter de solución que ofrecen. Las normas legales son aplicables por completo o no son aplicables en lo absoluto (...). Pero no es así como actúan los principios (...). Aun los que semejan mucho normas legales no establecen consecuencias jurídicas que se produzcan indefectiblemente al cumplirse las condiciones previstas $(\ldots)^{\prime \prime}$. Dworkin, R, ¿Es el Derecho un sistema de normas?" Filosofía del Derecho, México DF, Fondo de Cultura Económica, 1977, pp. 89-90.
} 
oportuno resulta concretar una explicación coherente que deje sentadas las bases para posteriores análisis. ${ }^{98}$

El iusnaturalismo, hegemónico ${ }^{99}$ en los estudios filosóficojurídicos hasta el siglo XIX y con importante virtualidad en el $\mathrm{XX},{ }^{100}$ es la tendencia en razón de la cual se puede explicar la esencia más remota de los principios generales del Derecho. En efecto, la dualidad de órdenes jurídicos que propone esta doctrina, ${ }^{101}$ esto es, el derecho natural entendido como referente y el derecho positivo enjuiciado desde la concordancia o no con esos mandatos dirigentes, posibilitan la defensa de la existencia construcciones de Derecho fuera del ordenamiento jurídico positivo. Estas construcciones, los principios generales del Derecho en este caso, son deducciones abstractas del concepto superior que ha de marcar las pautas de las relaciones jurídicas positivas. Este concepto ha sido variable en la historia, ${ }^{102}$ lo que hace que los principios generales hayan asumido la envoltura de ser consecuencia de la ordenación cosmológica de los antiguos, de las ideas objetivas platónicas, de la substancia aristotélica, de la razón divina o de la razón humana. Claro está que no se puede hablar en los inicios de la especulación sobre el derecho natural de la denominación que en la actualidad es manejada, pues obviamente las manifestaciones del fenómeno son muy anteriores a su encuadramiento jurídico.

\footnotetext{
98 Para conocer la opiniones más representativas que sobre este tópico ha formulado la doctrina española vid Beladiez Roso, M, op. cit, pp. 39-55.

99 En expresión de PASSERIN: "(...) durante más de dos mil años, la idea del Derecho natural ha desempeñado un papel preeminente en el pensamiento y la historia de Occidente (...)". Passerin D’ Entréves, A, La dottrina del Diritto Naturale, Milán, Comunitá, 1980, p. 13.

100 Autores como José María Rodríguez Paniagua entienden que el estudio de la doctrina iusnaturalista deviene en una efectiva introducción al Derecho. Cfr. Rodríguez Paniagua, J. M, Lecciones de Derecho Natural como introducción al Derecho, Madrid, Universidad Complutense, 1988, pp. 11-67.

101 Cfr. García Márnez, E, La definición del Derecho. Ensayo de perspectivismo jurídico, Xalapa, México, Biblioteca de la Facultad de Derecho de la Universidad Veracruzana, 1948, pp. 47 y ss.

102 Apud Peces Barba, G, Introducción a la Filosofía del Derecho, Madrid, Editorial Debate, 1983, pp. 208-242. También vid Rodríguez Paniagua, J. M, op. cit, p. 11 y ss.
} 
El iusnaturalismo aporta la potencialidad fenoménica a los principios generales, ${ }^{103}$ dejando establecida su posibilidad óntica (de ser), y es que, si se quiere, todo el derecho natural es un corpus de principios en sí mismo, que apreciando condicionamientos diversos, sirve de substancia y de instrumento de legitimación del derecho positivo. ${ }^{104}$ Así, son entendidos como guía y fundamento en los procesos de creación, interpretación y aplicación del derecho, en virtud de encarnar los ideales de orden, justicia o racionalidad que deben ineludiblemente imperar en la dinámica de las relaciones sociales, fijándoseles en este sentido caracteres de permanencia, trascendencia y superioridad, ${ }^{105}$ lo que no desdice que la aplicación de

${ }^{103}$ En opinión de Ahrens: "( ...) todo derecho reside en una relación de derecho, y este, completamente definido, es una relación entre personas, concerniente a un objeto, engendrado por un hecho particular, determinado por un principio o una regla de derecho, para un fin de la vida humana (...) este principio debe considerarse en su parte ideal y en su parte real y positiva, porque en todo derecho hay que examinar la idea fundamental y las formas por la que ella se expresa en la vida real y se hace una regla positiva, formalmente obligatoria entre los hombres; y finalmente, tenemos que comprobar las relaciones que existen entre estos dos principios (...); el derecho (...) es un principio que, lejos de ser un simple producto de la voluntad humana, es una ley inherente a las relaciones de vida, constituidas por las leyes de desarrollo del hombre y de la sociedad, y por todas la fuerzas físicas y morales que obran en la vida, y el derecho, que manifiesta la conformidad de la voluntad con estas relaciones, exige la sumisión de la voluntad a las leyes que se desprenden de ellas (...)". Ahrens, E, Curso de Derecho Natural o de Filosofía del Derecho. Completado en las principales materias, con ojeadas históricas y políticas, Madrid, Librería Extranjera y Nacional, Científica y Literaria, 1873, pp. 140-141.

104 Sobre el rol legitimador del derecho natural para con el derecho positivo vid, Díaz, E, Curso de Filosofía del Derecho, Madrid-Barcelona, Marcial Pons, Ediciones Jurídicas y Sociales, S.A, 1998, pp. 19-41.

${ }^{105}$ Apud Cossio, C, op. cit, p. 246. En opinión del padre de la teoría egológica: “( ...) Los principios generales del Derecho, son así, estos juicios estimativos de valor general o supremo capaces de determinar la conducta de los hombres en razón de su intrínseco valor, de manera que faltando la norma legal que configure el comportamiento, siempre sea posible traer a cuento una norma que surja de aquel juicio estimativo preexistente a la acción legislativa, y al juicio de valor original que ella pueda implicar. (...). Hoy la ciencia jurídica, a este respecto, ha vuelto en parte a la posición de la Escuela jusnaturalista, y ha vuelto notablemente enriquecida después de la experiencia del siglo XIX (...). Es claro que este regreso a los puntos de vista de la Escuela de Derecho Natural no es un regreso puro y simple. Más que a la Escuela de Derecho Natural, la ciencia jurídica de nuestra época ha regresado al derecho 


\title{
dichos ideales adopte consecuencias mudables en relación con la realidad social en cuestión. ${ }^{106}$
}

\author{
En Italia, Giorgio Del Vecchio asume esta propensión en sus \\ estudios generales de Filosofía del Derecho, también inmersa \\ en sus reflexiones particulares sobre el tema en cuestión. ${ }^{107}$
}

natural, que aquella escuela vio con aciertos y desaciertos igualmente notables. El Derecho ligado esencialmente a la naturaleza humana y la naturaleza humana empapada de una metafísica inteligible, son cosas que se han fortalecido casi unánimemente en la Filosofía jurídica contemporánea (...). Este modo estimativo cognoscible e invariable, a diferencia de otros modos estimativos imprevisibles y mutables, nos permite hablar de un ideal de la razón de variable contenido en los términos de un derecho natural, porque su fundamento participa, sin moverse, del movimiento de la historia, tal como el punto céntrico de una esfera permanece inmóvil en su movimiento de rotación. Ésta es la idea de justicia; así en la historia hay lugar para una justicia racional al lado de la justicia irracional; y si ambas valoraciones tienen para la historia el mismo sentido en cuanto justicia, en cambio sólo a la razón pertenece la idea de la justicia y, con ella, las valoraciones del primer tipo (...). Estos juicios estimativos de justicia conformes con la razón son los principios generales del Derecho a que se refiere el legislador cuando, como en el caso de nuestros codificadores, se está en las vías del derecho natural y cuando se confía a la razón la tarea de llenar las lagunas de la legislación, con preferencia a otros criterios estimativos (...)". Cossio, C, op. cit, pp. 249, 250, 256 y 257.

106 Los comentarios de ReCAséns Siches a la obra de Francisco SuÁrez son ilustrativos a estos efectos: "(...) los principios generales se aplican a la esencia moral del hombre -que es común a todos-, producen normas invariables; pero ruando se proyectan sobre una materia social variable, producen normas cuya validez está condicionada a la existencia de determinadas situaciones concretas; y, así, con el mudar de éstas, cambian también las normas de Derecho natural. He aquí, pues, cómo se dibuja un ensayo de justificada articulación de los criterios estimativos ideales y objetivos con la variedad y con los cambios de la realidad social. La materia social es varia y mudadiza; y, así, ocurre que, aun cuando los primeros principios de Derecho natural sean inmutables, sucede que, al ser aplicados a esa materia social, que aquí es diferente de allá y que se transforma al correr del tiempo, dan lugar a normas también diversas (...)". ReCAséns Siches, L, Tratado General de Filosofía del Derecho, México DF, Editorial Porrúa, 2008, p. 430.

107 En opinión de Del Veccho: "( . . . Tan erróneo sería negarse a reconocer y concebir dentro de su especie (la del Derecho) un dato jurídico cualquiera alegando que su contenido no está de acurdo con el ideal, como desconocer este ideal y el valor que le es propio fundándose en que se haya realizado en algún caso de la experiencia jurídica. La verdadera índole del ideal no consiste en suponer que se verifique siempre de hecho en la realidad empírica, sino en considerarlo tal y como es, como esencialmente supraordinado a esta realidad, es decir, como algo que tiene vigencia y es verdadero, aun cuando se le opongan eventualidades físicas (...). El Derecho Natural es, pues, el criterio que permite valorar el Derecho Positivo y medir la intrínseca justicia del mismo (...); el cumplimiento de tal valoración es 


\title{
Mientras que en España, Legaz y Lacambra adopta una visión cultural con marcados tintes sociológicos que engarza con la tradición cristiana occidental. ${ }^{108}$
}

\author{
Las palabras de estos dos maestros, alzadas en pleno siglo \\ $\mathrm{XX}$, cuando los estudios iuspositivistas cuajaban en todo su
}

una exigencia insuprimible de la razón y del sentimiento (...)". Del Vecchio, G, Filosofía del Derecho, Barcelona, Editorial Bosch, 1942, pp. 483 y 488. En lo relativo a los principios generales este maestro italiano consagra una línea idéntica al defender que: "(...) los intérpretes contemporáneos están de acuerdo, casi sin excepción, en declarar que por principios generales del derecho no deben entenderse los principios del derecho natural. Se considera generalmente como un triunfo de la moderna Jurisprudencia el haber derrocado la antigua escuela del Derecho Natural, para dejar paso a una visión exclusivamente histórica o positivista del fenómeno jurídico, según las enseñanzas fundamentales de la Historische Rechtsschule alemana, depurada por el transcurso del tiempo de algunos de sus elementos románticos y metafísicos. Verdad es que, como es sabido, el primer intento de aquella fue precisamente oponerse a la idea de la codificación, por lo cual, al menos bajo este aspecto, su decantado triunfo semeja una victoria de Pirro; cierto es, además, que los nuevos Códigos acogieron e hicieron suyos en gran parte los principios del individualismo racional, en que había culminado la especulación iusnaturalista de la época precedente; hasta el punto de que un maestro de la disciplina histórica -GIERKE- pudo con justicia hacer notar el singular fenómeno de la victoria material (materielle Siege) que el Derecho natural experimentó por obra de la escuela adversa, después de su ruina formal. Esto no obstante, la negación del Derecho natural se considera todavía generalmente como un indispensable acto de fe y casi un deber de buena crianza para el jurista; de lo cual tenemos precisamente una prueba en la presteza con que, interpretando la fórmula antes indicada, se suele, ante todo, negar que contenga alusión alguna a tal derecho, como si se tratara de alejar una sospecha injuriosa (...)". Del VecCHIO, G. Principios..., op. cit, pp. 3-5.

108 Para este autor: "(...) una visión escalonada de los principios generales del Derecho ayudaría mucho a zanjar distintas dificultades que suscita su problemática. Puede afirmarse que las legislaciones de los pueblos modernos civilizados tienen en su base, aproximadamente, los mismos principios generales del Derecho. Pero estos principios no son nunca vividos en un estado de pureza originaria, por así decirlo. En su última instancia, se trata de verdades jurídico-morales y religioso-teológicas propias de la civilización cristiana. En el curso de esta civilización, estas verdades han experimentado una serie de concreciones a través de las distintas concepciones filosóficas y políticas e incluso en virtud de la mutación de las circunstancias sociales y vitales del hombre. Así, el cristianismo ha descubierto la verdad de que el hombre es persona en cuanto hombre; pero esta verdad fundamental presenta matices diferenciales - a veces hondamente diferenciales- en la Edad Media y en la Edad Moderna, en la filosofía escolástica y en el racionalismo, en el fascismo y en el individualismo liberal (...)". Legaz y Lacambra, L, Introducción a la Ciencia del Derecho, Barcelona, Editorial Bosch, 1943, p. 402. Un seguidor de estas ideas, BAsave Fernández deL Valle, A, op. cit, pp. 666 y ss. 
esplendor, responden a un movimiento de rescate iusnaturalista que había florecido en Francia, en la voz fundamental de GéNy, como reacción a la exégesis derivada del Code de 1804. ${ }^{109}$ Esta coyuntura tiene una profunda influencia en la configuración naturalista de los principios generales del Derecho. Desterrados del sistema de fuentes de la obra magna de Napoleón como consecuencia de una hiperbólica interpretación de la teoría política de MonTEsquieu, los principios generales del Derecho son revividos por GéNY como herramientas, en virtud de las cuales se podían concebir pautas interpretativas más amplias, sobre la base de entender que la ley no era todo el Derecho y, por ende, que en ella no se expresaba toda la pulsión social que este estaba llamado a regular. ${ }^{110}$ Sin lugar a dudas ha sido el Consejo de Estado, en el entorno francés, el órgano que ha mantenido con vida la aplicación de los principes généraux $d u$ Droit, delineando importantes posturas doctrinales al calor de su jurisprudencia administrativa, cuestión a la que JEANNEAu dedicó importantes reflexiones. ${ }^{111}$

En Alemania, es justo destacar el impulso perspectivo que supuso la exaltación de los argumentos sociológicos de la Escuela del Derecho libre, ${ }^{112}$ cuyo eje expositivo, como bien resumió STERnberg, radica en defender que todo Derecho, por

109 GÈnY, F, “L'Évolution contemporaine de la pensée juridique dans la doctrine française," Le Droit Privé...., op. cit, pp. 3 y ss.

${ }^{110}$ GénY, F. Método..., op. cit, pp. 235 y ss.

111 Cfr. Jeanneau, B, Les principes généraux du Droit dans la Jurisprudence Administrative, Préface de M. Jean Rivero, Paris, Éditions du Recueil Sirey, 1954, pp. 7 y ss.

112 Un análisis crítico al respecto en SternBerg, T, op. cit, pp. 158-164. Explicaba al respecto Hernández-Gil que: "(...) la afirmación de un Derecho libre, vivo, espontáneo, anterior y superior al impuesto estatalmente, ya implica una posición sociológica, aunque no siempre en todo momento los propulsores del Derecho libre hayan tenido consciencia y practicado un método propiamente sociológico. Quien más clara cuenta se dio de esto fue Ehrlich; en él se conjugan la concepción del Derecho libre y la sociología del Derecho como base metódica en que apoyarla. En cambio, en Kantorowicz, por lo menos inicialmente, late vivo un anarquismo individualista, aunque luego se adentre en los derroteros sociológicos trazados por Ehrlich (...)". Hernández-GIL, A, op. cit, 252-254. 
más que se tenga por puramente nomocrático, es una transacción entre nomocracia y sofocracia. ${ }^{113}$

Igualmente, LARENZ matizó el iusnaturalismo en cuanto a la existencia de los principios jurídicos con su concepto de Derecho justo, mostrando interesantes toques eclécticos, pues si bien entiende que la búsqueda de estos debe comenzar por lo que está efectivamente positivado, considera insuficiente esa búsqueda si no se remonta el análisis a los pensamientos más primigenios que justifiquen la regulación. Estos pensamientos originarios tienen un marcado condicionamiento ético, que en buena medida es el medidor de legitimidad que garantiza la realización plena de la ordenación social. ${ }^{114}$

Claro resulta que la idea de un derecho natural, entendido como sostén de todo el andamiaje jurídico positivo, y por ende legitimador de la existencia de postulados genéricos que sirvan de guía y referente, tanto constructivo como interpretativo, ${ }^{115}$ a

113 Sternnerg, T, op. cit, p. 158. Sigue la cadencia expositiva este autor afirmando que: “(...) las garantías objetivas que se dan en la subjetividad de la conciencia jurídicamente cultivada, seleccionada en las actividades del juez, abogado y profesor de Derecho, según los principios establecidos por la sofocracia, son mucho más vigorosas que la superstición en unos poderes absolutamente objetivos de la Ley y de la Ciencia, que no existen en modo alguno, pero que en realidad precisamente la más cómoda guardia a la arbitrariedad, a la insensibilidad y a la falta de espíritu (...)". SternBerg, T, op. cit, pp. 158-159.

114 Cfr. Larenz, K. Derecho justo..., op. cit, pp. 32 y ss. Del mismo autor vid Metodología..., op. cit, p. 203 y ss. En esta última obra se deja en claro que: “(...) al interpretar las leyes (con vistas a la resolución de casos jurídicos) no puede pasarse por alto que en ellas no se trata de enunciados cualesquiera, sino de prescripciones que han de obedecerse, de pautas de juicio prescritas, brevemente: de normas. El legislador que promulga una ley, o más exactamente que pretende regular un determinado sector de vida por medio de normas, se deja guiar al respecto por ciertas intenciones reguladoras y por consideraciones de justicia o de oportunidad, a las que en último término subyacen ciertas valoraciones (...)". LARENZ, K. Metodología..., op. cit, p. 203.

115 En la literatura española el administrativista Fernando GarRido FaLLA ha entendido a los principios generales del Derecho, en una de sus variantes, como principios del Derecho natural: “(...) los principios generales del Derecho remiten a una fuente normativa distinta y autónoma respecto del Derecho escrito positivo (...), concebidos en esta acepción, los principios generales del Derecho, deben considerarse cómo fuente del Derecho administrativo, y precisamente fuente subsidiaria. Y a pesar en que la jurisprudencia contencioso-administrativa 
dicha organización, no ha transitado pacíficamente por el contrapunteo de la reflexión jurídico-filosófica. Tanto el historicismo como el positivismo han atentado contra sus fundamentos, poniendo en tela de juicio su existencia misma, lo que lógicamente supone, en virtud de la más elemental relación entre lo genérico y lo particular, una ruptura de la dupla sinónima principios generales del Derecho-principios del derecho natural, que fue estrenada en el espacio codificado por el Código austriaco de 1811.

A pesar de tenerse plena conciencia de la importancia que el iusnaturalismo ha tenido en la orfebrería misma de la idea de principios generales del Derecho, no solo directamente, pues la reacción a estos derroteros también han enriquecido sobremanera la cuestión, justo es indicar que la profusión con que se ha mostrado esta doctrina a lo largo de su desarrollo atenta contra las bases de seguridad y legalidad que han de caracterizar a la actividad jurídica. Dicho de otra forma, la indeterminación configurativa del iusnaturalismo, claramente advertida por Werner GOLDSCHMIDT, ${ }^{116}$ ha propiciado una indeterminación configurativa de los principios generales del Derecho, llegando a ser entendidos estos como entelequias imposibilitadas de concreción, permeadas de relativismo y subjetivismo, cuya única finalidad es la de controvertir el orden jurídico (positivo) establecido. ${ }^{117}$

del Tribunal Supremo ha invocado tales principios para fundamentar sus decisiones; pues, entendidos como principios del Derecho natural pueden significar un último reducto al que el juez puede jurídicamente acogerse en el trance de cumplir con su obligación de sentenciar. Ahora bien, si existe una ley positiva contraria a lo que el juez (o el administrador) estime ser un principio del Derecho natural, no tiene más remedio -en nuestro sistema- que aplicar la ley y olvidarse del principio. Y posiblemente no debamos lamentarnos de que así sea, pues de los tiempos en que el imperio de la ley escrita aún no se había consagrado con su actual carácter absorbente, es aquel rancio adagio del Derecho francés, recordado por RiveRo: Dios nos guarde de la equidad de los Parlamentos (...)". Garkido Falla, F, Tratado de Derecho Administrativo, Vol. I. Parte General, Madrid, Editorial Tecnos, 1994. p. 264.

${ }^{116}$ Cfr. Goldschmidt, W, Filosofía, Historia y Derecho, Buenos Aires, Librería de Valerio Abeledo, 1953, p. 145.

117 En la doctrina italiana de la primera mitad del siglo pasado esta cuestión tuvo una importante virtualidad. En palabras de CHIRoNI: "(...) Questi principi generali sono constituiti 
José Castán Tobeñas dejó en claro el asunto cuando afirmó que: “(...) no es del todo infundado el temor de que el recurrir a los principios generales del Derecho, a través de una interpretación puramente filosófica (léase iusnaturalista) ${ }^{118}$ de los mismos, significase la puerta abierta por la que se introdujera la inseguridad jurídica, desde el momento que el juez podría sustituir el criterio relativamente fijo de la ley por el que movedizo y subjetivo de su arbitrio (...)". ${ }^{119}$

Otra flaqueza resaltada por los detractores del derecho natural en lo que compete a los principios generales del Derecho, se desprende de la pretendida inmutabilidad que este supone. En efecto, si el iusnaturalismo se concibe desde una perspectiva condicional del derecho positivo para con construcciones

dai criteri ai quali la legislazione informa l'ordinamento fondamentale suo: il giudice li ottiene invertendo il processo di formazione della legge, spogliandola cioè delle disposizioni particolari e complesse onde si reggono le figure dei vari rapporti, e risalendo ai concetti più semplici formanti le nozioni originarie del diritto com è. Concetti comuni ai vari istituti regolati; e per tal comunanza, formano questi principi l'analogia di legge (...)". Chironı, G. P, Istituzioni di Diritto Civile Italiano, Vol. I, Milano-Torino-Roma, Fratelli Bocca Editori, 1912, p. 24. Unos años antes, en una obra escrita a cuatro manos con ABELlo, este autor había dicho que: "( . . ) questi principii generali son fissati dallo studio filosofico del diritto e i materiali dell' analisi e della sintesi in cui son riuniti qual risultato, vengono forniti della conoscenza del diritto vigente e di tutti i motivi che lo imposero o lo consigliarono. Varranno a tal fine tutte le tradizioni legislative che hanno in qualche modo preparato l'attuale diritto e sopratutto il diritto romano inteso non nel senso di vera e propia legge -opinione ormai abbandonata- ma nel senso di elemento suppletivo alla possibile deficienza delle leggi vigente per la risoluzione di speciali controversie e la conoscenza esatta delle ragioni economico-sociali, cui la legge volle provvedere. Solo il giurista-sociologo può adunque scorgere nella maggior nettezza loro questi principi di diritto, che, al pari della consuetudine, sono fonti mediate del diritto e non possono igualmente derogare alla legge positiva (...)". Chironi, G. P. y L. Abello, Trattato di Diritto Civile italiano, Vol. I. Parte Generale, Torino, Fratelli Bocca Editori, 1904, p. 52. También vid Venzı, G, Manuale di Diritto Civile Italiano, Torino, Unione Tipografico-Editrice Torinese, 1938, pp. 17-18; D’Amelı, M, Codice Civile. Libro Primo (Persone e Famiglia). Commentario, Firenze, S. A. G, Barbèra, Editore, 1940, pp. 19-20; Puglatti, S, Introducción al estudio del Derecho Civil, México DF, Editorial Porrúa Hnos. y Cia, 1943, p. 65, y Messineo, F, Manual de Derecho Civil y Comercial, Traducción de Santiago Sentis Melendo, tomo I. Introducción, Buenos Aires, Ediciones Jurídicas Europa-América, s/a, p. 66. 118 La aclaración es mía.

119 CAstán Tobeñas, J, Metodología de la aplicación e investigación del Derecho, Madrid, Editorial Reus, 1947, p. 337. 
abstractas inmutables, ¿cómo defender el carácter dinámico de los principios generales del Derecho pendiente del ambiente cultural, social y político de un momento histórico determinado?

La mayoría de los embestidas a la doctrina del derecho natural se han sistematizados desde un posicionamiento iuspositivista, ${ }^{120}$ derivación iusfilosófica que, junto a la primera, constituye uno de los dos grandes polos de toda las problemáticas sucedidas en la evolución de las ideas jurídicas en clave filosófica. La cuerda fundamental que con respecto a los principios generales del Derecho se desprende de los postulados positivistas ${ }^{121}$ es casi

${ }^{120}$ La crítica de HART, por ejemplo, ataca el sentido lógico y la precisión terminológica del naturalismo, así como su funcionalidad en sede jurídica. En su obra cumbre, El concepto de Derecho, este importante autor inglés sistematizaba al respecto lo siguiente: "(...) muchos críticos modernos han pensado que la pretensión de que las normas o leyes de conducta correcta pueden ser descubiertas mediante la razón humana descansaba en una simple ambigüedad de la palabra ley y que cuando esta ambigüedad fuese denunciada, el derecho natural recibiría un golpe mortal. Es de esta manera que John Stuart Mill alude a Montesquieu, quien en el capítulo primero de L'Esprit des Lois pregunta ingenuamente por qué, mientras que las cosas inanimadas, tales como las estrellas y también los animales, obedecen a la ley de su naturaleza, el hombre no procede así, sino que incurre en pecado. En esto, pensaba MııL, se hace patente la perenne confusión entre las leyes que formulan el curso o las regularidades de la naturaleza, y las leyes que exigen que los hombres se comporten de ciertas maneras. Las primeras, que pueden ser descubiertas mediante la observación y el razonamiento, bien pueden ser denominadas descriptivas y corresponde al científico descubrirlas; las últimas no pueden ser establecidas así, porque ellas no son enunciados o descripciones de hechos, sino prescripciones o exigencias de que los hombres se comporten de cierta manera. Por lo tanto la respuesta a la pregunta de MontesQuieu es simple: las leyes prescriptivas pueden ser transgredidas y no obstante siguen siendo leyes, porque ello significa simplemente que los seres humanos no hacen lo prescripto; pero carece de sentido afirmar que las leyes de la naturaleza, descubiertas por la ciencia, pueden o no pueden ser transgredidas. Si las estrellas se comportan de manera contraria a las leyes científicas que pretenden describir sus movimientos regulares, éstas no son transgredidas, sino que pierden su título a ser llamadas leyes y tienen que ser reformuladas. A estas diferencias en el sentido de ley corresponden diferencias sistemáticas en el vocabulario asociado, compuesto de expresiones tales como tener que, deber, etc. Así, según este modo de ver, la creencia en un Derecho o Ley Natural es reducible a una falacia muy simple: no percibir los sentidos muy diferentes que estas palabras y expresiones pueden tener. Es como si el que sustenta esa creencia no percibiera el muy diferente sentido de esas palabras en Ud. tiene que presentarse al servicio military si el viento sopla del Norte, tiene que nevar (...)". HaRT, H. L. A, op. cit, pp. 231-232.

${ }^{121}$ Una síntesis valiosa de estos postulados en AleXY, R, El concepto y la validez del Derecho, Barcelona, Gedisa Editorial, 1994, pp. 13-19. 
la síntesis de todo su andamiaje categorial, a saber: no existen construcciones jurídicas más allá de los límites del ordenamiento jurídico, en consecuencia, a estos se llega a través de un ejercicio de inducción intelectual, es decir, de extracción de la dinámica de todo el derecho positivo de un conjunto de axiomas, abstractos y generales, que contienen en sí mismos todo el sentido y toda la esencia de este y que le sirven de fundamento y de guía. No propone entonces una dialéctica bilateral entre lo general y lo particular, pues el método defendido solo es instrumentable si se toma como punto de partida lo concreto, esto es, la norma positivada. $^{122}$

El paradigma normativo de esta postura lo constituye el ya visto párrafo segundo, artículo 12, del Codice italiano de 1942, que rompiendo con la tradición nacional consagró la máxima principios generales del ordenamiento jurídico del Estado, en sustitución de la expresión principios generales del Derecho vigente, que había sido debatida en la década de 1930 en los trabajos preparativos de tan importante cuerpo legal ${ }^{123}$ como

\footnotetext{
${ }^{122}$ Al respecto sostuvo Federico De Castro y Bravo que: “(...) la reacción del positivismo contra el dogmatismo vacío y caprichoso del Derecho natural individualista lleva consigo la aspiración de borrar toda regla jurídica fuera de la ley. La dificultad que suponía la imperfección e insuficiencia de los textos legales se trataba de superar aplicando los métodos de las ciencias naturales. La materia jurídica, conformada en cuerpos jurídicos y construcciones jurídicas, se convierte, mediante un proceso de progresiva generalización, en el sistema; su importancia está en que, elaborada sola y exclusivamente sobre la base de las disposiciones legales, se piensa que es una fuente inagotable de nueva materia, que sirve para completar al Derecho positivo (...)". De Castro y Bravo, F, op. cit, p. 413. Por su parte, Margarita Beladiez Roso resumía estos contornos afirmando que: "(...) para los positivistas en general, y sin perjuicio de las diferencias que puedan existir entre las distintas tendencias, los principios sólo se pueden encontrar atendiendo al texto legal, ya sea en su estricta literalidad, o acudiendo a los hechos externos que motivaron esa decisión del legislador; pero teniendo en cuenta que la fuerza de esos hechos deriva precisamente de la razón de ser de la ley. Sólo cuando han sido contemplados por el legislador es posible tenerlos en cuenta para la aplicación del Derecho (...)". Beladiez Roso, M, op. cit, pp. 32-33.
}

123 Según BobBı “(...) Este cambio fue explicado en la Relación del Ministro con estas palabras: (...). En lugar de la fórmula principios generales del derecho vigente, que habría podido parecer demasiado limitante para la actuación del intérprete, hemos creído preferible esta otra, principios generales del ordenamiento jurídico del Estado, en la cual el término 
una medida de protección ante la intromisión de elementos extraños en la dinámica del ordenamiento jurídico. ${ }^{124}$ En la doctrina italiana CARNELUTTI ${ }^{125}$ apoyó la reforma, mientras que Del Vecchio se pronunció con fuerza en su contra catalogándola de retroceso y tildando la nueva expresión de impropia. ${ }^{126}$ No obstante, en opinión del español De CASTro y Bravo, la regulación del Código de 1865 en relación con los principios

ordenamiento resulta compresivo, en su más amplio significado, más allá de las normas y de las instituciones, también de la orientación político-legislativa estatal y de la tradición científica nacional (derecho romano, común, etc.). Tal ordenamiento, adaptado o sancionado por el Estado, o sea, nuestro ordenamiento, tanto privado como público, dará al intérprete todos los elementos necesarios para la búsqueda de la norma reguladora (...)". Boвві0, N. Teoría..., op. cit, pp. 249-250.

124 Vid, Trabucch, A, Istituzioni di Diritto Civile, Padova, CEDAM, Casa Editrice Dott, Antonio Milani, 1956, pp. 8-9 y 37-39.

${ }^{125}$ Explica Carneluttı que: “(...) Los principios del derecho son, pues, las reglas no expresadas de que derivan, a través de su aplicación a los casos previstos, los preceptos formulados con carácter general o particular. El principio es, naturalmente, más amplio que el precepto que de él deriva; por eso puede servir a la formación del precepto que se necesita para el caso. Y puede servir de dos maneras: si el precepto expreso es aplicación del principio, formando un precepto semejante a éste; si, por el contrario, el precepto expreso es excepción del principio, formando un precepto contrario. Por eso se comprende en el procedimiento analógico tanto el argumentum a simili como el argumentum a contrario (...). Por su mayor amplitud en comparación con el precepto que de él deriva, el principio no es jurídico; si la juridicidad se dan en el mando que, en su aplicación a la realidad, se resuelve en el acto de mandar, lo que queda fuera no puede ser derecho. Los principios del derecho no son, en sí mismos, derecho; la materia prima que sirve para formar el producto no puede ser el producto (...). El principio, pues, no puede formarse, sin más, teniendo en cuenta la ética o la economía, sino que debe rodearse de aquellas reglas éticas o económicas que han guiado al legislador y que quizás pudieran también ser, y lo son con frecuencia, falsas en vez de verdaderas. Los principios del derecho no son, pues, derecho, sino pura ética y economía, cuyas premisas éticas o económicas han sido extraídas, mediante la inducción, del material legislativo. Para evitar toda duda respecto del particular, en la redacción recientísima del artículo 3 (...) la frase principios generales del derecho se ha cambiado muy oportunamente por la de principios generales del ordenamiento jurídico del Estado (...)". Carnelutti, F, Teoría General del Derecho, Madrid, Editorial Revista de Derecho Privado, 1941, pp. 118 y ss.

${ }^{126}$ Apud Del Vecchio, G. Filosofía..., op. cit, p. 337; y especialmente, Del VecCHIO, G, “Riforma del Codice civile e principi generali del Diritto," Rivista Internazionale di Filosofia del Diritto, Ano XVIII, Fascículo I, Roma, 1938, pp. 10 y ss. 
generales ya había empezado a interpretarse desde la perspectiva positivista ${ }^{127}$ desde mucho antes. ${ }^{128}$

Como se observa, el interés de la línea positivista es potenciar la funcionalidad de los principios generales en correlato con la salvaguarda de la seguridad jurídica (entendida en el sentido derivado de la ideología de la revolución burguesa acaecida en Francia) ${ }^{129}$ y el principio de legalidad, pues a consideración de sus exponentes la extrapositividad que propone el iusnaturalismo, tendente al subjetivismo y al relativismo, atenta contra la plena integridad y coherencia del ordenamiento jurídico. No obstante estas operativas intenciones, lo cierto es que la variante iuspositivista limita y desnaturaliza la esencia de los principios generales, pues los subsume, en cuanto a su contenido y objetivos de existencia, en el mismo entorno normativo que está llamados a colmar, limitando de esta forma toda su raigambre histórica y todo su condicionamiento cultural. Un autor de relevancia como Del Vecchio identifica esta tendencia como el método analógico, apostillando que es imposible que la generalización salde todos los vacíos regulativos que pueden dejar las leyes. ${ }^{130}$ La doctrina española ha visto en ella un círculo vicioso (una vida de cárcel diría PuIg PeÑa) ${ }^{131}$ que supone una

\footnotetext{
${ }^{127}$ Las palabras de Nicolás Covielto resumen claramente la directriz positivista en torno a los principios generales del Derecho: "(...) tales principios no pueden ser otros que los principios fundamentales de la misma legislación positiva, que no se encuentran escritos en ninguna ley, pero que son los presupuestos lógicos necesarios de las distintas normas legislativas, de los cuales en fuerza de la abstracción deben exclusivamente deducirse. Pueden ser de hecho principios racionales superiores, de ética social, y también principios de derecho romano, y universalmente admitidos por la doctrina; pero tienen valor no porque son puramente racionales, éticos o de derecho romano o científico, sino porque han informado efectivamente el sistema positivo de nuestro derecho, y llegado a ser de este modo principios de derecho positivo y vigente (...)". Covielto, N, Doctrina General del Derecho Civil, México D.F, Unión Tipográfica Editorial Hispano-Americana, 1938, pp. 96-97.

128 De Castro y Bravo, F, op. cit, p. 413.

${ }^{129}$ Un análisis preciso al respecto en Sarmiento García, J, Los principios en el Derecho Administrativo, Mendoza, Ediciones Diké-Foro de Cuyo, s/a, pp. 31-34.

130 Del Vecchio, G. Filosofía..., op. cit, p. 338.

131 Puig Peña, F, Tratado de Derecho Civil Español, tomo I, Parte General, Vol. I, La norma jurídica, Madrid, Editorial Revista de Derecho Privado, 1957, p. 335.
} 
vulneración del componente identitario de los principios generales, entendidos en consecuencia, desde una mira endógena, como preceptos legales. ${ }^{132}$

Atinadamente Federico De Castro y Bravo apuntó desde un posicionamiento crítico que: "(...) El error de esta dirección doctrinal está en confundir los principios lógicos o abstracción científica con los principios jurídicos creadores (...)" ${ }^{133}$

Estas palabras del civilista español ponen de relieve un elemento constante en la crítica al positivismo, no compartido

132 Para Mans Puigarnau: “(...) prácticamente significaría casi negar la virtualidad de los principios jurídicos como fuente jurídica independiente, pues en realidad no entraría en vigor ninguna norma supletoria, y, en consecuencia, no nos moveríamos de un círculo vicioso. La mera aplicación de los principios en que se inspira el propio sistema legal no sería suplir plenamente la insuficiencia de la ley y de la costumbre, sino aplicar el derecho por el procedimiento analógico, que es la forma más restringida de dar paso a los principios generales. Toda vez que se limitan a los inspiradores del sistema vigente. Añádase a esto que el principio de derecho contenido en la ley, prácticamente ya no es principio como fuente supletoria: es precepto legal (...)". Mans Puigarnau, J. M, op. cit, p. Xll. Pérez Luño también se proyectó en consonancia con esta línea de exposición al afirmar que: "(...). La concepción positivista de los principios se enfrentó con un doble escollo: porque, si los principios generales del derecho consisten en procesos discursivo tendentes a extender las consecuencias previstas en las leyes a otros supuestos no contemplados en ellas, en nada se diferencian de la analogía y, por tanto, resultan superfluos (...). Además, a tenor de la célebre crítica de Giorgio Del VecCHo, la concepción positivista de los principios supone, en definitiva, duplicar el papel de la ley como fuente del derecho, que lo sería de forma directa y expresa y de forma indirecta y tácita a través de los principios generales del derecho entendidos como meras generalizaciones de la propia ley (...)". Pérez Luño, A. E. Los principios..., op. cit, p. 20. También vid las explicaciones de Beladiez Roso en el capítulo de su obra dedicado a la conceptualización de los principios generales del Derecho, especialmente lo referido a la matriz sociocultural que define su contenido.

133 Un poco más adelante aseveraba que: “(...) El principio obtenido por medio sólo de la lógica ha de coincidir, exactamente, con el conjunto total de conceptos dados, para que se haga la abstracción. Principios y materia de abstracción están en una relación de total interdependencia; el principio, para ser lógicamente tal, ha de corresponder en extensión y naturaleza al conjunto de datos suministrados, de tal forma, que si se obtuviera una regla que abarcase un solo supuesto no contenido ya en los datos, el principio dejará de ser principio de este conjunto concreto, para ser un principio distinto, el principio de un nuevo conjunto (el anteriormente supuesto más la nueva hipótesis subsumida). Ni los principios lógicos ni los criterios clasificatorios pueden crear nueva materia al conocerla o al clasificarla. La fuerza creadora del sistema sólo puede admitirse cometiendo una confusión metodológica 0 un engaño político (...)". De Castro y Bravo, F, op. cit, p. 413. 
por un sector importante de la doctrina italiana, ${ }^{134}$ consistente en reclamarle el desconocimiento del intríngulis evolutivo del orden jurídico y el papel que en su realización juegan los principios generales del Derecho en su acepción creativa (perspectiva exógena), esto es, como construcciones jurídicas que, por no depender exclusivamente del orden positivo, pueden introducir criterios novedosos, es decir, pueden aclimatar las soluciones jurídicas a la dinámica de situaciones socio-históricas puntuales. Esto se conecta con otra cuestión que se deriva de la más elemental lógica formal: si los principios generales son el resultante de un proceso de abstracción que toma como materia primigenia a la ordenación positiva, ¿cómo sistematizar un principio general cuyo contenido no está completamente volcado en dicha ordenación positiva?

Claramente, la estrechez relacional entre lo positivado y la posibilidad configurativa de los principios generales que promueve el positivismo, si bien pondera un orden de pleno señorío de la ley, lo que en cierta medida puede tributar a la seguridad jurídica, ahoga indiscriminadamente la dimensión social del Derecho, sumiéndolo en un franco y evidente estatismo, a la vez que en un estatalismo, ${ }^{135}$ pues concentra su

\footnotetext{
${ }^{134}$ La doctrina italiana, tanto anterior como posterior al Codice de 1942, identificó el tratamiento de los principios generales del Derecho con el de la analogía. Desde la iusfilosofía vid Groppalı, A, Filosofia del Diritto, Milano, Ulrico Hoepli, Editore Libraio della Real Casa, 1906, pp. 175 y ss; Cogloolo, P, Filosofia del Diritto Privato, Firenze, G. Barbéra Editore, 1912, pp. 52 y ss; Donatı, B, Fondazione della Scienza del Diritto, Parte Prima di Una. Introduzione alla Scienza del Diritto, Milani-Padova, Casa Editrice Dott-Già Litotipo, 1929, pp. 157 y ss; y Cosentini, F, Filosofia del Diritto, Torino-Roma-Milano-Firenze-Napoli-Palermo, Ditta G. B. Paravia e Comp. , 1914, p. 58. Desde los estudios civilistas vid BARASSI, L, Istituzioni di Diritto Privato, Milano, Dott. A. Giuffré-Editore, 1940, pp. 21-27; Barbero, D, Diritto Privato italiano, tomo I, Milano, Unione Tipografico-Editrice Torinese, s/a, p. 79; DE Ruggiero, R, Istituzioni di Diritto Civile, Vol. I, Introduzione e parte generale, Diritto delle persone, Messina-Milano, Casa Editrice Giuseppe Principato, 1934, pp. 71-75; y Rotondı, M. (s/a). “Equità e principii generali del Diritto nell'ordinamento giuridico italiano," Recueil D'Etudes sur les sources du droit. En L'Honneur de François Gény. Les sources générales des systèmes juridiques actuels, Paris, Libraire du Recueil Sirey, s/a, p. 406.

${ }^{135}$ El nuevo paradigma postmoderno niega este posicionamiento al proponer la pluralidad de fuentes. A juicio de Moderne: "(...) la sociedad civil descartará cada vez más abiertamente
} 
creación exclusivamente en los engranajes estatales destinados a tales efectos.

En armonía con lo expuesto se puede concluir que tanto los iusnaturalistas como los iuspositivistas han pecado de unilaterales en sus análisis con respecto a los principios generales del Derecho, pues en su afán de responder a esquemas filosóficos fijados ab initio han perdido la perspectiva de la complejidad, esto es, de la variedad factorial y funcional que le son características. ${ }^{136}$

Una posición ecléctica ha de partir necesariamente de aquella máxima hegeliana que dejó en claro que: "(...) confundir la circunstancia de que el derecho natural o derecho filosófico es distinto del positivo, con que ambos sean recíprocamente opuestos y contrarios, sería un gran equívoco; más bien, uno y otro están entre sí en la misma relación que la Instituta con las Pandectas (...)" ${ }^{137}$ Así, aunque siempre ponderando sutilmente un extremo más que otro, la armazón iusfilosófica de los principios generales puede asumir elementos desplegados por ambas doctrinas sin necesidad de consagrar a ultranza ninguna de ellas. ${ }^{138}$ Debe aclararse que esta posición mixta no responde a un facilismo

el monocentrismo primordial normativo legado por el positivismo estatal para volverse hacia vías alternativas de regulación (término preferido al de normativización, muy marcado por la filosofía moderna) surgidas de centros normativos dispersos. El pluralismo de las racionalidades del derecho postmoderno sucederá así a la racionalidad única del derecho moderno; las lógicas hoy en día serían las de la flexibilidad, de lo vago, en una sociedad donde reinan lo complejo, las estructuras en rizo, las circularidades, etc. A esta desmultiplicación de las fuentes correspondería una desmultiplicación de los modos de regulación del derecho, admitiendo lo informal tanto como lo formal. Según algunos, el derecho se volvería, capilar, intersticial, incluso soluble o líquido, se infiltraría en todos los poros del tejido social (...)". Moderne, F, op. cit, pp. 57-58.

${ }^{136}$ Apud García Máynez, E. La definición...., op. cit, pp. 237 y ss.

${ }^{137}$ Hegel, J. G. F, Filosofía del Derecho, Buenos Aires, Editorial Claridad, S.A, 1968, p. 41.

${ }^{138}$ En el especio legislativo, este criterio es seguido por el Código Civil egipcio de 1949, que en su artículo 1 identifica a los principios generales del Derecho con los principios del Derecho islámico, el derecho natural y la equidad. La misma línea sigue el Fuero de Navarra en su artículo 4, al establecer que los principios en cuestión son los principios del derecho natural o histórico que informan el ordenamiento civil navarro y los que resultan de sus disposiciones. 
mimetista, sino a un ejercicio de rigor que identifica la afluencia de ambos cauces filosófico-jurídicos en la materia que se analiza, recreándose así la vieja máxima de Ascoli que profetiza que: "(...) de tales contradicciones no parece que pueda haber otra evasión sino en estas soluciones híbridas (...)”. ${ }^{139}$

Del derecho natural ha de tomarse la idea de subsistencia y de directrices informadoras, mientras que el positivismo jurídico, inclinado en varias de sus manifestaciones hacia la empiria, los inserta orgánicamente en el ordenamiento positivado, brindando a tales efectos herramientas para la formulación de métodos interpretativos y de integración del Derecho, alzando la idea de que estos deben ponderar premisas sociojurídicas básicas como son la seguridad y la legalidad.

En España ${ }^{140}$ un claro exponente de este posicionamiento mixto, con tendencia al iuspositivismo, lo constituye De Diego. En un interesante trabajo apreció el civilista que: "(...) pensar

\footnotetext{
139 Ascolı, M, op. cit, p. 31.

140 También Puigarnau es partidario de un criterio intermedio. En su ya citada obra este autor expresó que: "(...) Así, pues, frente a los conceptos parciales, restrictivos o limitativos del ámbito de los principios generales del derecho, nosotros proponemos un concepto total, 0 mejor integral, de los mismos, un concepto que se extiende no sólo a todas las ramas en que el derecho se divide, sino también a todos los aspectos en que se distingue y con que se presenta (...). Ni pueden limitarse a los del derecho natural o a los de la equidad, ni a los de un determinado sistema de derecho positivo, ni a los del derecho doctrinal o científico; sino que, por el contrario, los principios generales del derecho abarcan o comprenden todos aquellos conceptos fundamentales y preceptos básicos y elementales que inspiran la conciencia y el sentido jurídicos (principios de derecho y equidad naturales), y que informan el sistema de normas que regulan las instituciones (principios sistemáticos del derecho positivo) o la construcción doctrinal o teórica de las mismas (principios de la ciencia del derecho), y que rigen la realidad práctica de unas y otras (reglas del arte del derecho o reglas técnicas jurídicas) (...). Este concepto de los principios generales del derecho, no por amplio y compresivo deja de ser claro y preciso. Es un concepto integral que en nada entorpece el criterio relativo a la aplicabilidad de los mismos. En el orden práctico, ya lo dijimos: de todo el acervo de principios jurídicos, entrarán sólo en vigor, además de los que informan el sistema de derecho vigente (y que, por lo tanto, constituyen parte integrante del mismo), aquellas convicciones de la conciencia jurídica, aquellas conclusiones científicas y aquellas reglas fundamentales del derecho histórico que no se hallen en contradicción con el sistema de derecho positivo vigente, a juicio del primer organismo judicial de la nación, según hemos dejado sentado en el lugar oportuno (...)". Mans Puigarnau, J, op. cit, pp. XXVII-XVIII.
} 
en otros principios distintos delos que están embebidos en la obra general legislativa y de derecho de un pueblo (...) era tanto como abrir la puerta a la introducción de reglas exóticas que destruyesen las líneas de éste y entronizar la confusión y el desorden (...) Sólo en defecto de ésta (de la costumbre) podemos explotar los principios generales de derecho y es claro que han de ser los de la misma ley y costumbre, y cuando ellos no alcancen a satisfacer la necesidad del momento o a dar la solución requerida, entonces (...) hay que buscarla en la propia realidad social, investigada con criterio científico, fecundizada e iluminada por los principios de razón y de justicia (...)" ${ }^{141}$

Si bien se parte en la exposición precedente de comprender a los principios, primariamente, como portadores del espíritu y el sentido de la ley misma, se manejan variables como la razón, la justicia y la realidad social, a través de las cuales se les puede insuflar un contenido mucho más amplio que el expresado en la norma positiva. Esta visión dual demuestra fehacientemente que, en pos de lograr un posicionamiento unitario, se hace necesario apartarse de sectorialismos naturalistas y positivistas para realizar un ejercicio dialéctico que asuma de forma integral y combinada las aristas del fenómeno jurídico que estas doctrinas enarbolan como únicas y en ocasiones como excluyentes.

En la doctrina nacional MATILLA CORREA se ha proyectado advirtiendo que: “(...) esta teoría ecléctica goza de los beneficios de las posiciones intermedias, en relación con los extremos que trata de compatibilizar (...) sin embargo (...) al compendiar de modo unitario tendencias con presupuestos conceptuales diversos, es factible que dicha concepción cargue con una parte de las objeciones que pueden acompañar a tales tendencias, consideradas de manera singularizada. Igualmente, otro factor de recelo en lo que se refiere a esta teoría ecléctica, pasa por los inconvenientes o incoherencias que pueden presentarse en lo que constituye su punto de construcción esencial, pues en el afán de aunar

141 Clemente De Diego, F, “El método en la aplicación del Derecho Civil. Los principios generales del Derecho," Revista de Derecho Privado, No. 37, Año IV, Madrid, 1916, pp. 288, 294 y 300. 
criterios conceptuales diferentes, puede llegarse a un resultado forzado o incoherente (...)". ${ }^{142}$

Estos oportunos comentarios han de servir para comprender que de lo que se trata no es de sumar acríticamente los aciertos naturalistas y positivistas, sino de colegiar perspectivas que por naturaleza nunca se deben encontrar separadas. Se siguen así las exigencias más elementales para lograr la comprensión cabal del Derecho y de sus principios generales, entendidos como una de sus manifestaciones más importantes.

\section{Reflexiones en torno a las funciones de los principios generales del Derecho}

Razón le asiste a GuASTini cuando afirma que el dogma de la (necesaria) completitud de todo ordenamiento ${ }^{143}$ no parece fundado. En su favor han sido adoptados diversos argumentos, pero ninguno de ellos persuasivo. ${ }^{144}$ Este problema, como ya fue abordado, tiene orígenes históricos no tan recientes, pudiendo localizarse su escenario más candente en la Francia del siglo XIX y comienzos del XX, donde la disputa entre los exégetas y GÉNY arrojó importantes conclusiones. ${ }^{145}$ En la imposibilidad

\footnotetext{
142 Matilla Correa, A, “Comentarios sobre las fuentes del Derecho Administrativo cubano (excepto el Reglamento)," Temas de Derecho Administrativo cubano, tomo I, La Habana, Editorial Félix Varela, 2004, pp. 36-37.

143 Para ReCASÉns Siches la plenitud hermética del orden jurídico se justifica porque: "( . . ) el Derecho es esencialmente una relación de seguridad social, impuesta autártica o inexorablemente; y, por eso, cuando surge un conflicto interhumano, el Derecho ha de pronunciar forzosamente una decisión, bien de regulación positiva, por ejemplo, atribuyendo a alguien un determinado deber y a otro alguien un cierto derecho subjetivo; bien de garantía normativa, consagrando una esfera de libertad (por ejemplo, a nadie se puede obligar a tener una determinada creencia religiosa). Pero en uno y otro caso se trata de una decisión que es impuesta inexorablemente y que desvanece la incertidumbre y que suprime la inseguridad implicadas por el conflicto planteado (...)". Cfr. ReCAséns SicHes, L, Introducción al Estudio del Derecho, México DF, Editorial Porrúa, 1917, pp. 205-206.

144 Guastinı, R, Las fuentes del Derecho. Fundamentos teóricos, Lima, Editorial Científica, 2016, S.A.C, p. 516.

145 Consideraciones de valor al respecto en Grossı, P, De la codificación a la globalización del Derecho, Navarra, Editorial Aranzadi, 2010, S.A.
} 
de la realización del dogma de la totalidad regulativa ${ }^{146}$ del ordenamiento jurídico positivado, ${ }^{147}$ o de la completitud, para usar las palabras de GuASTINI, radica una las glándulas centrales de la funcionalidad de los principios generales del Derecho. ${ }^{148}$ El fenómeno jurídico, complejo y dinámico por excelencia, requiere, en su rol de ordenación de las relaciones sociales, la concurrencia de elementos estabilizadores (integradores) que posibiliten su plenitud, ${ }^{149}$

\begin{abstract}
146 Para VIGo: "(...) está claro que el Estado de Derecho Legal se nutrió de una teoría típicamente positivista en el sentido de que no había más derecho que aquel que así se había establecido autoritariamente, y cualquier contenido podía ser derecho en tanto el criterio de validez jurídica se definía completamente por el sistema jurídico al establecer el órgano y el procedimiento para crear la norma. No había derecho si alguna autoridad no lo había dispuesto como tal, y ella tenía libertad para brindarle cualquier contenido, dado que los eventuales defectos morales o axiológicos en nada afectaba a la existencia jurídica (...); la validez de la norma se asimilaba a su existencia sistémica y no a consideraciones extrajurídicas como las de carácter moral o axiológico (...)". VIGo, R. L, op. cit, p. 267.
\end{abstract}

147 Sobre este dogma y su crítica vid BobBı, N. Teoría..., op. cit, pp. 224-238

148 Para Gondillo Cañas este argumento es: “( ...) la razón de ser de la inclusión de los Principios en la enumeración de las Fuentes del Derecho (...)". Gordillo Cañas, A, Ley, principios generales y constitución. Apuntes para una relectura, desde la constitución, de la teoría de las fuentes del Derecho, Madrid, Editorial Centro de Estudios Ramón Areces, 1990, S.A, p. 42

${ }^{149}$ En la doctrina se han formulado un grupo de teorías que sostienen a priori la plenitud absoluta del ordenamiento jurídico. La que se deriva del iuspositivismo clásico, definida como teoría de los espacios vacíos, fue defendida, entre otros, por Bergbohm y seguida por Santi Romano (Romano, S, El ordenamiento jurídico, Madrid, Editorial del Instituto de Estudios Políticos, 1963). La médula de esta postura radica en sostener que las pretendidas lagunas no son más que espacios carentes de regulación en virtud de su poca relevancia social. Así, en buena técnica, no existen lagunas, sino situaciones y relaciones sociales a las que el Derecho no llega como consecuencia de un ejercicio de ponderación de la relevancia de las mismas. Según Romano (op. cit, pp. 316-317): "(...) se puede concebir perfectamente que un ordenamiento jurídico admita como principio fundamental la limitación a determinadas materias, de forma que las que quedan fuera hayan de ser consideradas como jurídicamente irrelevantes, formando por tanto un campo en el que no se reconocen ni derechos ni obligaciones. Y no se trata solo de una mera posibilidad, sino de una exigencia indeclinable de todo ordenamiento, si resulta cierto el axioma antes recogido de que ningún ordenamiento asume la pretensión de regular toda clase de actividades y manifestaciones individuales, sino simplemente las que interesan a sus fines $($...)". Otra derivación del dogma de la plenitud es la asumida por Zitelmann (Zitelmann, E, "Las lagunas del Derecho", en Savigny, Kirchmann, Zitelmann, Kantorowicz, La Ciencia del Derecho, Buenos Aires, Editorial Losada, 1989), cuyas pautas generales fueron abrazadas por Donatı (DonATI, D, II problema delle lacune dell'ordinamento giuridico, Milano, Società Editrice Libraria, 1910, pp. 28-56 y 126 y ss.) y por KeLSEN (KeLSEN, H, El método y los conceptos fundamentales 
siendo la categoría que se trata un ejemplo clásico a este tenor. ${ }^{150}$

A los efectos de este análisis ha de quedar esclarecido el hecho de que los principios generales pueden o no estar positivados, lo que les confiere el carácter de explícitos o implícitos, respectivamente, operando una sinonimia formal entre principios y reglas en el primer caso, solo diferenciables por la extensión de sus enunciados. Esto responde al hecho de que las normas, entendidas como construcciones lógicas, pueden ser, en efecto, explícitas o implícitas.

Según Éric Millard, una norma es el significado de un enunciado prescriptivo. Así, una norma jurídica es explícita cuando: "(...) constituye la escogencia de una interpretación de un enunciado dado como jurídica (Constitución, ley, contrato, etc.), en un marco de interpretación aceptable desde un punto de vista estrictamente lingüístico, fuera de toda consideración axiológica (...)" ${ }^{151}$ En otro sentido, es implícita una norma jurídica cuando:

de la teoría pura del derecho, Traducción de Luis Legaz y Lacambra, Madrid, Editorial Revista de Derecho Privado, 1933). Con relación al tema este último afirmó que (op. cit, pp. 65-66): “(...) no existen lagunas auténticas en el sentido de que no fuese posible decidir un litigio con arreglo a las normas vigentes, porque no se pudiese aplicar la ley por falta de un precepto que hiciese referencia al caso. (...). El orden jurídico no solo contiene el principio de que se está obligado a una determinada conducta, sino también el contrario: se es libre de hacer u omitir aquello a lo que no se está obligado. Esta norma es la que se aplica cuando se decide negativamente la pretensión de que se realice una conducta no obligatoria (...)". La diferencia de la teoría defendida por esta tríada de autores con respecto a la de los espacios vacíos radica en su enfoque lógico. El presupuesto de partida se localiza en la máxima que reza que todo aquello que no está expresamente prohibido está permitido. Así, las pretendidas lagunas no son más que un lógico correlato de un espacio de libertad determinado. Al respecto vid también las explicaciones de Cossio, C, op. cit, pp. 19 y ss. Igualmente consultar a BuLYGIN, E, "La importancia de la distinción entre normas y proposiciones normativas," en Bulygin, E, M. Atienza y J. C. Bayón, Problemas lógicos en la teoría y práctica del Derecho, Madrid, Fundación Coloquio Jurídico Europeo, 2009, pp. 9-73. Una crítica desde la doctrina cubana en Ferrari Yaunner, M, op. cit, pp. 43 y ss.

150 Apud Pérez LuÑo, A. E, El desbordamiento de las fuentes del Derecho, Discurso leído el día 12 de diciembre de 1993 en el acto de su recepción pública en la Real Academia Sevillana de Legislación y Jurisprudencia, Sevilla, Publicaciones de la Real Academia Sevillana de Legislación y Jurisprudencia, 1993, pp. 13 y ss;

${ }^{151}$ Millard, É, Teoría general del derecho, Traducción de Bernardo Carvajal Sánchez, Bogotá, Universidad Externado de Colombia, 2016, p. 152. 
“(...) no constituye la escogencia de una interpretación de un enunciado (creación monopolizada), ya sea porque se sale del marco de interpretación aceptable o porque se sustenta en otra cosa (...)" ${ }^{152}$ No obstante seguir este autor francés los cauces de una teoría analítica, cuyos presupuestos no han sido observados en la exposición anterior, la clasificación propuesta da paso a una conclusión importante, a saber: cunado la catalogación de una norma como principio no se deriva de la propia actividad de la autoridad normativa, o sea, cuando no es explícita, su cualidad principalista puede estar dada por una variedad de influencias, cuya concreción se logra a través de un ejercicio de interpretación.

Ahora bien, esta posibilidad de suplir a través de los principios generales una falencia en la regulación positivada (o consuetudinaria en su caso) se debate entre dos posturas extremas, a saber: la necesaria habilitación al respecto en el sistema de fuentes de un Estado determinado, o la instrumentalidad innata de estos sin ser necesaria dicha legitimación expresa.

Prima facie, se presenta un obstáculo de comprensión que requiere una evacuación inmediata, a saber: la multilateralidad metodológica de la cuestión de las fuentes del derecho. ${ }^{153}$ A tales efectos la opinión de Ross ha devenido en todo un paradigma. ${ }^{154}$

\footnotetext{
152 Millard, É, op. cit, p. 153.

153 Una visión didáctica al respecto en GoltzBeng, S, Les sources du Droit. Que sais-je? Paris, Presses Universitaires de France, 2016, pp. 7-14 y 37-85. En opinión de este autor: "( ...) Les principes généraux du droit occupent un statut intermédiaire entre la loi et éthique, ainsi qu'entre la règle et le cas. Ils ont une portée générale, non absolue, ce qui rend possible l'opposition entre deux principes généraux du droit : alors que deux règles opposées conduisent à un conflit de lois, deux principes peuvent s'opposer sans que naisse une anomalie qu'il faudrait résoudre une fois pour toutes. En cela, les principes généraux du droit sont des arguments topiques (par opposition à "logiques ") par excellence. Ils ont connu une reconnaissance croissante. À la différence de beaucoup de lois, on prévoit moins bien leur portée (...)". GoltzberG, S, op. cit, p. 84.

154 Ross, A, Teoría de las fuentes del Derecho. Una contribución a la teoría del derecho positivo sobre la base de investigaciones histórico-dogmáticas, Madrid, Centro de Estudios Políticos y Constitucionales, 2007, pp. 356 y ss.
} 
Resumidamente, los problemas al respecto pueden ser planteados al tenor siguiente:

- Configuración de una perspectiva sociológica del Derecho que determina las causas de existencia de un determinado sistema jurídico y que puntualiza en el aparato causal de los actos que, en dicho sistema, son creadores de Derecho.

- Afloramiento de una problemática ética jurídica que intenta discernir sobre el fundamento moral de la vinculación del ordenamiento jurídico y que puede ser sintetizada en un principio general.

- El problema teórico jurídico, volcado en el reconocimiento preciso del origen de las normas jurídicas y en la determinación de algo como Derecho.

Esta triple perspectiva, de la que se desprenden conclusiones referidas al conocimiento, la producción, la legitimación y la instrumentalidad de lo jurídico en las decisiones razonadas de los jueces, pone de relieve la proporcionalidad existente entre el concepto de fuente y la visión iusfilosófica general de la multidimensionalidad del Derecho como fenómeno cognoscible. Si bien desde la teoría del Derecho se potencia la tercera de las aristas, entre otras cosas porque en ella confluyen (o debieran confluir) las dos anteriores, lo cierto es que la presencia de los principios generales del Derecho en la dinámica de la organización jurídica se manifiesta en cada una de ellas, ${ }^{155}$ es decir, como resultado

\footnotetext{
${ }^{155}$ El criterio de Diez-PICAzo en este sentido resulta un poco exagerado, pues entiende rígidamente la correlación existente entre el poder efectivo de los principios generales y el poder de sus órganos formuladores, desconociendo a la par la variedad de procesos y condicionantes que los pueden contener como una de sus resultantes: "( ...) El problema se torna especialmente crítico cuando se trata de buscar un poder normativo en los llamados principios generales del Derecho, pues resulta casi imposible de encontrar. Tiene que ser una especie de espíritu colectivo o de alma colectiva: la sociedad entera moviéndose en la historia, con lo cual en lugar de Sociología hacemos Metafísica, pero no resolvemos un problema que sea en puridad jurídico. Y si tratamos de ser más realistas y concretos acabaremos por confundir el poder concreto que se realiza a través de los principios generales del Derecho con el poder que ostentan los órganos a los cuales se concede el poder de la formulación
} 
sociológico que engloba los movimientos de la vida organizada de una comunidad dada, como reservorio de los paradigmas éticos que fundamentan las bases jurídicas de la misma y como punto originario del entramado normativo y como criterio de identificación y de congruencia ab intra del mismo.

En la correlación entre los conceptos fuente material (de raigambre sociológica) y fuente formal (de raigambre técnicojurídica) se localizan los fundamentos de una respuesta coherente en este sentido, dejando de lado por ahora la ambigüedad metafórica que caracteriza al concepto fuente, puesta de relieve por Enrico PARESCE en la Enciclopedia del Diritto. ${ }^{156}$ Entiéndase por fuente material al acto genérico (no interesa su nomen, su procedimiento formativo o el órgano del que dimana) que produce normas, siendo imposible encasillar a priori a dicho acto en marcos formales. En otro sentido, la idea de fuente formal supone una autorización en lo atinente al acto de producción normativa, es decir, concurre una fijación a priori de su nombre, de su procedimiento formativo y del órgano emisor. ${ }^{157}$

A la luz de estas dos formas de entender la manifestación de las fuentes del Derecho, y asumiendo que lo común en la cultura jurídica romano-francesa es apropiarse de posturas eclécticas, ${ }^{158}$

de tales principios (...)". Díez-PICAZo, L, "La doctrina de las Fuentes del Derecho", Anuario de Derecho Civil, tomo XXXVII, fascículo IV, Madrid, Ministerio de Justicia, octubre-diciembre de 1984, p. 941.

156 Díez-Picazo, L. "La doctrina..., op. cit, p. 935.

157 Un estudio detallado sobre el tema en Aftalión, E. y J. Vilanova, Teoría general de las fuentes del Derecho (y del orden jurídico), Barcelona, Editorial Ariel, 2000, in integrum. También vid Balaguer Callejón F, Fuentes del Derecho. Ordenamiento Constitucional, Madrid, Editorial Tecnos, 1992, in integrum.

158 Aclara GuASTINI que: "(...) si bien la alternativa entre concepción material y concepción formal de las fuentes es bastante clara, lo mismo no puede decirse sobre la concepción de las fuentes efectivamente adoptada por los juristas en nuestra cultura jurídica. De hecho, la noción de fuente ampliamente dominante en la doctrina jurídica no parece ser ni puramente material, ni puramente formal, sino mixta o ecléctica. En el sentido de que, para identificar las fuentes del derecho, los juristas usan sea un criterio formal, sea uno material. Por un lado (criterio formal), tienden a considerar fuentes del derecho todos los actos que están 
cabe preguntarse si la instrumentalidad y el sentido de los principios generales del Derecho se inutilizan si estos no aparecen consagrados en un sistema con carácter de fuente formal, o lo que es lo mismo, si no está autorizada formalmente su aplicación para la solución de determinados casos, perfilándose lo que GORDILLO CAÑAs ha dado a llamar modestia de su rango normativo. ${ }^{159}$ Una respuesta afirmativa redunda en un positivismo vulgar, no coincidente con la nueva teoría de las fuentes que reseña PerLINGIERI, ${ }^{160}$ mientras que una respuesta negativa asume plenamente otro de los grandes patrones funcionales que ellos asumen, a saber, el de ser la base misma del ordenamiento jurídico, ${ }^{161}$ guía de la aplicación del derecho ${ }^{162}$ e instrumento de interpretación (tanto

autorizados a producir normas, incluso cuando, de hecho, no tienen contenido normativo (como ocasionalmente ocurre). Por el otro (criterio material), tienden a considerar, además, fuentes del derecho todos los actos que, de hecho, producen normas, incluso si no existe ninguna norma sobre la producción jurídica que los autorice a producirlas (...)" GUASTINI, R. Las fuentes..., op. cit, p. 104. También vid Aparisı, A. y F. López, “Fuentes del Derecho," en De LucAS, J, Introducción a la Teoría del Derecho, La Habana, Editorial Félix Varela, 2006, pp. 299-342.

159 Gordillo Cañas, op. cit, p. 41.

160 Cfr. Perlinglerl, P, "Por un Derecho civil constitucional español," Anuario de Derecho Civil, tomo XXXVI, fascículo I, Madrid, Ministerio de Justicia, enero-marzo de 1983, pp. 14-15.

161 Para De Diego: “(...) Los principios elaborados en el seno de la sociedad por obra, en definitiva, no hay necesidad de decirlo, de la razón individual permanecen como en el subsuelo de las formaciones jurídicas; ellos alumbran al legislador y al obscuro iniciador del Derecho consuetudinario, Ilevan la dirección del progreso jurídico y forman como la reserva normal de las nuevas apariciones o creaciones de derecho. Evidente nos parece que en ese primer aprovechamiento de los principios no quedarán éstos agotados y como consumidos y dispersos en las normas particulares dictadas por el legislador, y es natural suponer que al invocar éste los principios generales del derecho para suplir las lagunas de sus disposiciones, habrá querido referirse a aquellos principios que ya utilizó, y cuyo rico contenido ofrece como espléndida cantera para la formación de nuevas reglas (...)". Clemente De Diego, F. El método..., op. cit, p. 294. También vid, Rivera, J. C, Instituciones de Derecho Civil. Parte General, tomo I, Buenos Aires, LexisNexis, Abeledo-Perrot, 2004, pp. 152-153.

162 Freixes Sanjuán y Remottı Carbonell han expresado que: “(...) Los principios, en cuanto instituciones jurídicas con proyección normativa, cumplen con una función informadora de todo el ordenamiento. Esta función es más concreta que la realizada por los valores (de ahí su diferencia funcional con los mismos), ya que a partir de su mayor grado de precisión (pues, aun cuando son indeterminados, son predictibles), los principios ofrecen mayores argumentos para decidir el significado concreto de una regla. Así, también, de los principios se extraen reglas aplicables a los casos concretos, y la posible trasmutación de los principios en reglas 
de las leyes como de las costumbres), receptáculo de raigambre histórica, técnica y de valores socioculturales que posibilitan la fisura del monopolio estatal absoluto en la creación jurídica. En referencia del profesor Matilla Correa: "(...) los principios generales del Derecho funcionan, simplemente, como el Titán Atlas con respecto al Derecho Positivo (...)". ${ }^{163}$

La directriz política a la que responde el sistema de fuentes formales de cualquier país ${ }^{164}$ no puede atentar contra la lógica del funcionamiento jurídico, a esa aludida dialéctica entre lo general y lo particular donde los principios son un resultado a la vez que un escalón de partida; no puede invalidar, materialmente, la posibilidad de recurrir a construcciones no positivadas que asistan a la cohesión del ordenamiento, así como a la superación de sus defectos congénitos. ${ }^{165}$

supone el ejercicio de diferentes opciones de política legislativa (...)". Freixes Sanjuán, T. y Remotti Carbonell, J.C, "Los valores y principios en la interpretación constitucional," Revista Española de Derecho Constitucional, No. 35, Año 12. Madrid, Centro de Estudios Constitucionales, mayo-agosto de 1992, p. 103. También consultar los comentarios al respecto ARCE Y FlóREZ-VALDÉs, J, Los principios generales del Derecho y su formulación constitucional, Madrid, Editorial Civitas, 1990, pp. 54-55. A juicio de este autor: "(...) tres son las funciones atribuidas a los principios generales del Derecho, a saber: fundamentadora, interpretativa y supletoria, en relación con las demás fuentes, porque así se desprende del carácter informador que se les atribuye (...)".

163 Matilla Correa, A, Comentarios..., op. cit, p. 191.

164 Con tino, expresaron Diez-PICAZo y Gullón que: “(...) La enumeración y el establecimiento de la jerarquía de las fuentes es, ante todo, un problema político porque entraña el especial reconocimiento de un ámbito de poder -poder mandar y poder hacerse obedecer-, que en última instancia es un poder de naturaleza política (...)". Diez-Picazo, L. y A. Gullón, op. cit, p. 101. Con similares argumentos se pronunció sobre la cuestión Jean Rivero al sostener que: "(...) Entre los elementos que dan a los diversos sistemas jurídicos su originalidad, es preciso situar en primera línea la teoría de las fuentes del Derecho adoptado por cada uno de ellos. Según triunfe en la elaboración del Derecho positivo, lo consuetudinario, la acción del juez o la regla escrita emanada de la autoridad pública, se llega a estructuras jurídicas tan diferentes como el derecho del Ancien Regime francés, la Common Law británica o el régimen del Código civil napoleónico (...)". Rivero, J, "Los principios generales del Derecho en el Derecho Administrativo francés contemporáneo," Revista de Administración Pública, No. 6, Año II, Madrid, Instituto de Estudios Políticos, septiembre-diciembre de 1951, p. 289.

165 Este criterio fue compartido por Legaz y LacAmBRA: “( ...) es preciso reconocer la eficiencia de los principios generales de Derecho como fuente jurídica, aun en aquellos sectores del 
Los principios generales han de estar incorporados en el aparato categorial de razonamiento jurídico de quienes están facultados para aplicar el Derecho, ${ }^{166}$ en pos de enriquecer y brindar coherencia (racionalidad) al sistema jurídico, insuflándole un contendido más profundo, flexible y axiológicamente satisfactorio, que permita al jurista ver más allá de lo regulado en las leyes.

En este último sentido cabe traer a la palestra las ideas de Nino, que con mucha fuerza han abogado por un redireccionamiento de los estudios teórico-jurídicos hacia la optimización de la práctica, sobre todo en lo concerniente a la realización de los conceptos morales, teniendo una importante presencia en su argumentación el tema de los principios generales. Según este filósofo del Derecho: “(...) Esta dimensión de la teoría jurídica no es más que una especialización del discurso moral (...) Al igual que en el discurso moral ordinario, esta modalidad de teorización frente al derecho persigue justificar los juicios valorativos acerca de la solución correcta para ciertas clases de casos, mostrando que ellos derivan de un sistema coherente de principios generales (...)". ${ }^{167}$

Este razonamiento trae al campo de la funcionalidad la ya analizada matriz ética que caracteriza a los principios generales

Derecho en los que no aparecen expresamente mencionados 0, por el contrario, se hallan traducidos en normas jurídicas incompletas, como declaraciones de principios (...)". Legaz y Lacambra, op. cit, p. 405. Vid comentarios al respecto en Puig Brutau, J, La jurisprudencia como fuente de Derecho. Interpretación creadora y arbitrio judicial, Barcelona, Editorial Bosch, 1958, pp. 15-49.

${ }^{166}$ Una panorámica sobre la aplicación de los principios generales del Derecho por el magno foro cubano en ArREDondo SuÁreZ, I, "Los principios generales del Derecho en el sistema de fuentes del ordenamiento jurídico cubano," Matilla Correa, A, Panorama de la Ciencia del Derecho en Cuba. Estudios en homenaje al profesor Dr.C Julio Fernández Bulté, La Habana-Palma (Mallorca), Universidad de la Habana-Lleonard Muntaner Editor, 2009, pp. 181-192; de la misma autora vid, “ ¿Principios generales del Derecho en el sistema de fuentes?," Revista Justicia y Derecho, No. 14, año 8, La Habana, Tribunal Supremo Popular de la República de Cuba, junio de 2009, pp. 39-53;

167 Nino, C. S, Introducción al análisis del derecho, Buenos Aires, Editorial Astrea, 2003, p. 344. 
del Derecho, cuya naturaleza no descansa exclusivamente en ser un mero resultado de síntesis de la vida jurídica de una sociedad en interacción con las construcciones morales que esta arroja, sino que deviene en un meridiano informador de la interpretación y aplicación del Derecho, a la vez que un cúmulo notable de pautas argumentativas que permiten, sobre todo al juez, formular decisiones coherentes y con posibilidades elevadas de realización y legitimación.

En la doctrina se han manejado dos criterios fundamentales en lo atinente a la aplicación de los principios generales, ${ }^{168}$ estos son: el método analógico ${ }^{169}$ y el de generalización ascendente y abstracta de la norma particular, ${ }^{170}$ siendo este último un proceso a través del cual el juez realiza análisis escalonados tendentes a la generalidad, que mantienen elementos sustanciales de la construcción normativa base e incorporan nuevas derivaciones jurídicas ${ }^{171}$. En la doctrina argentina CAssagne ${ }^{172}$ entiende que este procedimiento puede configurar la aequitas cerebrina, esto es, el arbitrio judicial contra legem.

\footnotetext{
168 El profesor Matilla Correa ha advertido que: “( ... el el proceso de aplicación de los principios generales del Derecho, que está en manos de los órganos facultados para aplicar el Derecho (esencialmente los tribunales), es mucho más complejo que el de aplicación de una ley 0 costumbre, por las condiciones de determinación que están presentes en las dos últimas y de indeterminación que se patentiza en los primeros. Debido a la falta de precisión exacta de los principios generales del Derecho (no ya en su fuente genérica, sino en cuáles son ellos individualizadamente), su actividad aplicativa debe estar rodeada de una gran cautela, pues la existencia o planteamiento del principio general a utilizar pueden verse contaminados, y por ende adulterados, con apreciaciones subjetivas provenientes del órgano encargado de su aplicación (...)". Matilla Correa, A, Comentarios..., op. cit, p. 193.

169 Una aproximación conceptual al respecto en BoвBı, N. Teoría..., op. cit, pp. 245-249.

170 Apud Ferrajol, L, Epistemología jurídica y garantismo, México DF, Distribuciones Fontamara, 2004, pp. 75 y ss; y GuAstinı, R. Estudios..., op. cit, pp. 137-142. En la doctrina nacional vid Matilla Correa, A, Comentarios..., op. cit, p. 192; Ferrari Yaunner, M, op. cit, p. 103.

${ }^{171}$ Al respecto vid las explicaciones de Guastinı, R. Estudios...., op. cit, pp. 139 y ss; y de Puig Brutau, J, Estudios de Derecho Comparado. La doctrina de los actos propios, Barcelona, Editorial Ariel, 1951, pp. 97-101.

172 Cassagne, J. C, "Los principios generales del Derecho en el Derecho Administrativo", Estudios de Derecho Público, Buenos Aires, Ediciones Depalma, 1995, p. 12.
} 
En relación con la analogía, ${ }^{173}$ entendida desde la perspectiva metódica, y la aplicación de los principios generales del Derecho, entendidos como el material necesario para desarrollar este método, resulta notorio que es la analogía iuris la que presenta mayor vocación en este sentido, pues materializa el carácter transversal que estos suponen en toda la alineación jurídica. ${ }^{174}$ Este razonamiento sería aplicable a la analogía legis si se entendiera que todas las reglas están sustentadas en principios, deduciendo a esta sustentación como un fenómeno que brinda legitimidad a estas ab intra del sistema. ${ }^{175}$

Como sostuvo Prieto Sanchís: “(...) la obtención de los principios implícitos tiene bastante que ver con la analogía, pues el uso de la analogía implica siempre la generalización a partir de una o varias normas del ordenamiento jurídico, es decir, presupone el reconocimiento de un principio general. Tal vez la diferencia consiste en una menor tendencia a la generalización en el caso de la analogía legis que en el caso de la analogía iuris (...)". ${ }^{176}$ Con esta exposición se ha de llegar a una conclusión:

\footnotetext{
173 Vid, Bettı, E, op. cit, pp. 69-84. Para este maestro italiano: "(...) L'impostazione data al problema dell'analogia dai seguaci del dogma della volontà legislativa (...) Non si trata, infatti, di sapere come avrebbe deciso il legislatore, se avesse fermato la sua consapevole attenzione sulle situazioni di fatto sfuggite alla sua previsione: non si trata, cioè, di andaré alla ricerca di una decisione verosimile o presumible di carattere ipotetico. Siffatta impostazione non si giustifica se non da un punto di vista decisionistico che tenda a concepire il Diritto, piuttosto che come prodotto di ratio, come imposizione di una voluntas, anche irrazionale, la quale stat pro ratione (...)".

${ }^{174}$ Apud AtIEnZA, M, Sobre la analogía en el Derecho. Ensayo de análisis de un razonamiento jurídico, Madrid, Editorial Civitas, S.A, 1986, pp. 63-66.

175 Según la apreciación de Prieto Sanchís: "(...) Las relaciones entre los principios y sus respectivas normas expresas no pueden reducirse a un esquema único, por ejemplo, del tipo general-particular; a veces, los principios son los fines que persiguen las normas, o los intereses que tutelan, o los valores en que se inspiran, o, en fin, sus consecuencias lógicas (...)". Prieto Sanchís, L, Apuntes de teoría del Derecho, Madrid, Editorial Trotta, 2011, p. 210. 176 Prieto Sanchís, L, op. cit, p. 210. También vid Carnelutti, F, op. cit, pp. 118-123. Para Atienza: "(...) los argumentos por analogía poseen también este mismo carácter inconcluyente pues, en realidad, argumentar a partir de principios y por analogía no son cosas muy distintas. La analogía no sería más que un supuesto de uso no explícito -o no tan explícito- de principios. La analogía presupone también la coherencia del derecho, e implica siempre un momento
} 
el método analógico no agota la funcionalidad de los principios generales del Derecho, pues si bien la institución de la analogía, sea iuris o legis según lo dicho, supone necesariamente el despliegue de determinado (s) principio (s), estos pueden ser aplicados directamente a través del juicio de valor adecuado, manifestado, explícita o implícitamente, en el pertinente ejercicio argumentativo. ${ }^{177}$ En una relación género-especie asumen los principios generales la posición genérica, siendo la analogía una de sus varias formas de manifestación. Sostener lo contrario sería realizar una apología de la visión iuspositivista, obviando el carácter de substancia y el rol informador que a estos compete.

Otra interpretación interesante sobre la perspectiva funcional de los principios generales, que destaca por su lógica

valorativo, pues las semejanzas entre los casos no se encuentran, sino que se construyen; se sustentan, precisamente, en razones de principio (...)". AtIENZA, M, Las razones del derecho. Teorías de la argumentación jurídica, México D.F, UNAM, 2005, p. 121. En la doctrina del patio la profesora Ferrari Yaunner ha tratado este asunto con sutileza. En ocasión de los resultados de su investigación doctoral expresó que: "(...) En aras de la salvaguarda de la legalidad, las legislaciones prefieren que se acuda a la analogía primeramente, pero esta no es sino un recurso técnico. Si se trata de un principio establecido en una norma, como principio explícito, el intérprete, recurriendo a la analogía, estaría a la vez aplicando el principio subyacente (...). Los principios son siempre fundamento, subyacen, ya sea en la analogía, en la costumbre, o en cualquiera de los métodos o fuentes a las que se acuda para integrar (...); se pretende afirmar que los principios del Derecho están presentes en toda acción de integración. Incluso, cuando se soluciona con el argumento a contrario, este también estaría sustentado en aquel principio que establece que todo lo que no esté expresamente prohibido, se presume permitido. La propia esencia de la necesidad de integrar se sostiene, desde el punto de vista procesal, en el principio del non liquet, y desde el punto de vista sustantivo en el principio de seguridad jurídica que imprime en el ciudadano la certeza de no quedar desprotegido a pesar de las lagunas, de lo que se deriva el presupuesto de la plenitud (...)". Ferrari Yaunner, M, op. cit, pp. 104-105.

177 Reale se pronunció en este sentido sosteniendo que: “( . . . la analogía consiste esencialmente en llenar una laguna existente en la ley, gracias a un raciocinio fundado en razones de semejanza, en la correspondencia entre ciertas notas características del caso regulado y las de aquel que no lo está. El recurso a la costumbre y a los principios generales no impide la apelación a la analogía, sobre todo si se tiene en cuanta que todo raciocinio analógico presupone la correspondencia entre las dos modalidades de lo real puestas en contacto (analogía entis) y conduce naturalmente al punto de los principios (...)". REALE, M, op. cit, p. 148. Consultar igualmente a Atienza, M, “Sobre Creación judicial del Derecho de Eugenio Bulygin," Bulygin, E, M. Atienza y J. C. Bayón, op. cit, pp. 118-119. 
organizativa e integradora de lo dicho hasta el momento, fue expuesta por Atienza y Ruiz Manero. ${ }^{178}$ La cuestión se puede analizar, según estos autores españoles, aludiendo a la dimensión explicativa y a la dimensión justificatoria de los mismos. En la explicación del Derecho los principios son piezas o instrumentos didácticos (leyes científicas) a través de los cuales se puede comprender una realidad determinada, atendiendo al grado de abstracción con que se pretenda descifrar dicha realidad, esto es, el Derecho en general, el ordenamiento jurídico en particular o un sector de este.

Por mediación de los principios generales se puede entender el funcionamiento de determinada institución en el conjunto del ordenamiento jurídico y en el sistema social, a la vez que permiten aprehender al Derecho no como una simple sumatoria de pautas sino como una realidad orgánica y sistémica (función sistematizadora) dotada de coherencia. ${ }^{179}$ Por este motivo conocer los principios tributa a un conocimiento anticipado de las problemáticas que se pueden derivar de una regulación a través de instituciones específicas.

En lo que interesa a la función de justificación, esta se puede entender en relación con el razonamiento y la argumentación en el campo del Derecho, dándose una interesante y compleja dinámica entre principios y reglas como categorías

\footnotetext{
${ }^{178}$ Atienza, M y J. Ruiz Manero, op. cit, pp. 14-19.

${ }^{179}$ Apud Prieto Sanchís, L, Constitucionalismo y positivismo, México DF, Distribuciones Fontamara, 1999, pp. 34-48; Reale, M, op. cit, pp. 147-149. En sinonimia ha dicho Sendín García que: "(...) los principios generales juegan un papel informador del conjunto del ordenamiento jurídico. Labor que se proyecta a su vez en una pluralidad de funciones. Así, en primer lugar, son elemento fundamentador del ordenamiento jurídico, dotando a éste de un sentido y una racionalidad propias, que impide su simple consideración como una mera conjunción de normas, más o menos armónica, para convertirlo en una unidad dotada de sentido (...)". Sendín García, M. A, "Los principios generales del Derecho en el Derecho Administrativo español," Los principios en el Derecho Administrativo Iberoamericano. Actas del VII Foro Iberoamericano de Derecho Administrativo, Valladolid y Salamanca, Escuela de Administración Pública de Castilla y León, 2008, pp. 435-436. También vid Hernández-Mendible, V. R. "Los principios generales del Derecho en el Derecho Administrativo," Los principios en..., op. cit, pp. 660.
} 
lógicas que, desde diferentes ángulos, conjugan soluciones a los más disímiles casos y participan de la explicación razonada de las mismas. ${ }^{180}$

Se puede evaluar al compás de lo dicho la notable funcionalidad de los principios generales del Derecho en toda la complexión jurídica, como "(...) pilares y paredes maestras del edificio jurídico (...)," 181 siendo errado considerar que la aplicación de estos ha de estar necesariamente mediada o condicionada por la existencia de una laguna de la ley. Esa es una concepción de antaño que no puede hacer coincidir sus argumentos con la realidad, dado que desconoce la justicialidad directa que los define y en virtud de la cual: “(...) se nos permitiría recurrir cualquier acto jurídico (excepto, claro está, los que tengan rango de ley formal y el principio no tenga rango constitucional) que haya sido dictado desconociendo el valor que en él se proclama (...)". ${ }^{182}$

Es una falacia pensar que los principios generales no poseen vocación de aplicabilidad directa, tanto más vinculante en cuanto vengan recogidos en la Constitución según ZAGREBelsky, ${ }^{183}$ puesto que si así fuera, ¿cómo se podría garantizar la irrestricta observancia y la plana realización del contenido que proponen? Sin temor a equívocos, esta potencialidad aplicativa es génesis y colofón de todo el entramado funcional descrito.

Como se ha visto, las funciones de los principios generales del Derecho son correlativas con la complejidad de su construcción ontológico-jurídica. Estos constituyen un elemento

\footnotetext{
180 Apud Carrió, G. R, Cómo estudiar y cómo argumentar un caso. Consejos elementales para abogados jóvenes, Buenos Aires, Editorial Abeledo-Perrot, 1989, pp. 45 y ss; También vid, Atienza, M, Tras la justicia. Una introducción al Derecho y al razonamiento jurídico, Barcelona, Editorial Ariel, S.A, 1993, pp. 119 y ss; y Gascón Abellán, M, La técnica del precedente y la argumentación racional, Madrid, Editorial Tecnos, 1993. pp. 15-49.

181 Reale, M, op. cit, p. 148.

182 Beladiez Rojo, op. cit, p. 159.

183 ZagreBelsky, G, op. cit, p. 117.
} 
implícito, un conjunto de ideas sistemáticas ${ }^{184}$ inherentes a la esencia misma de lo jurídico, razón por la cual su atención no depende del mero reconocimiento de su vinculación jurídica en una estructuración formal de fuentes. Son construcciones que sistematizan, brindan sustento y coherencia, $\operatorname{proyectan}^{185} \mathrm{y}$ racionalizan el orden de Derecho en una sociedad determinada, aunque claramente pueden ostentar el carácter de universales. A través de su estudio se puede, como dijera en ingeniosa referencia verniana el precitado Matilla CoRREA, realizar un viaje al centro del ordenamiento jurídico. ${ }^{186}$

\section{A modo de cierre}

En consonancia con lo expuesto, se presentan las siguientes ideas conclusivas:

- Los principios generales del Derecho tienen una existencia objetiva y su conceptualización integral está en necesaria concordancia con la visión global que sobre el Derecho se profese.

- Sólo desde una perspectiva multidimensional y compleja del fenómeno jurídico se puede construir una teoría cabal sobre los principios, que los diferencie de los valores y las reglas desde los predios de la lógica formal y desde su real operatividad jurídica y que encierre referencias condicionantes variadas, a saber: históricas, técnicas, políticas, culturales, consuetudinarias, sociales, entre otras.

\footnotetext{
184 Pound, R, "El Derecho y la Ciencia del Derecho en las teorías recientes," Revista jurídica argentina La Ley, tomo XXIX, Sección Doctrina, enero-marzo de 1943, p. 826. También vid Pound, R, An Introduction to the Philosophy of Law, United States of America, Yale University Press, 1930, pp. 34-36 y 116.

185 Según ValdeCASAS: "(...) Esta virtud o fuerza expansiva de los principios, gracias a la cual pueden servir para llenar las lagunas jurídicas, es la que tuvo en cuenta el legislador español al indicar al Juez su aplicación en defecto de la ley y costumbre (... .". VALDECASAS, G, op. cit, p. 333. También vid LARENz, K. Metodología..., op. cit, p. 363 y ss.

${ }^{186}$ Matilla Correa, A, Comentarios...., op. cit, p. 187.
} 
- La doctrina iusnaturalista constituye la materia prima de la arquitectura ontológica de los principios generales del Derecho, en virtud de potenciar la existencia de construcciones jurídicas fuera del ordenamiento jurídico que lo informen y lo determinen.

- La doctrina iuspositivista, por su parte, reduce el contenido de los principios generales del Derecho a la materia positivada, llegándose a ellos de forma unilateral a través de un procedimiento de razonamiento ascendente que obvia la más elemental dialéctica entre lo general y lo particular en la ciencia del Derecho.

- Los principios generales del Derecho realizan funciones disímiles. No pueden ser asociados únicamente con la metodología analógica, pues desempeñan igualmente un rol informador, de sistematización, de integración, de racionalización y de interpretación de toda la ordenación jurídica. 